\section{드므름 \\ EUROPEAN COOPERATION}

Front cover, from top to bottom and left to right:

Right mandible of the fish Sparus aurata (D. Medakovic, Rovinj, HR) Structure of the mineralized byssus of Anomia simplex, reconstructed by synchrotron $\mu C T$ (H. Birkedal, Aarhus, DK). Onset of nacre microstructure in the shell of the bivalve Pinna nobilis (S. Wolf, Erlangen, DE) Calcified skeletons of the Mediterranean sea urchin Arbacia lixula (J. Thomas, Dijon, FR) Internal structure of a broken spine of the sea urchin Arbacia lixula (J. M. Kanold, Stuttgart, DE)

9 783038355915

ISBN-13: 978-3-03835-591-5

Key Engineering Materials Vol. 672

Electronically available at $h t t p: / / w w w . s c i e n t i f i c . n e t$

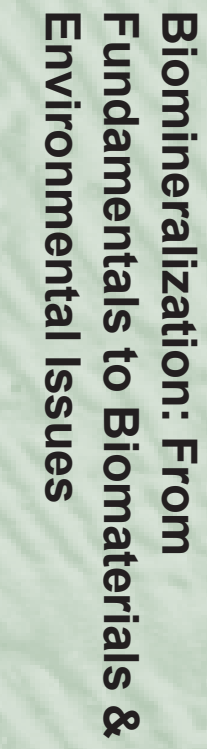

Frédéric Marin, Franz Brümmer, Antonio Checa, Gabriel Furtos, Isidoro Giorgio Lesci and Lidija Šiller

TTP
Biomineralization: From

Fundamentals to Biomaterials \&

Environmental Issues

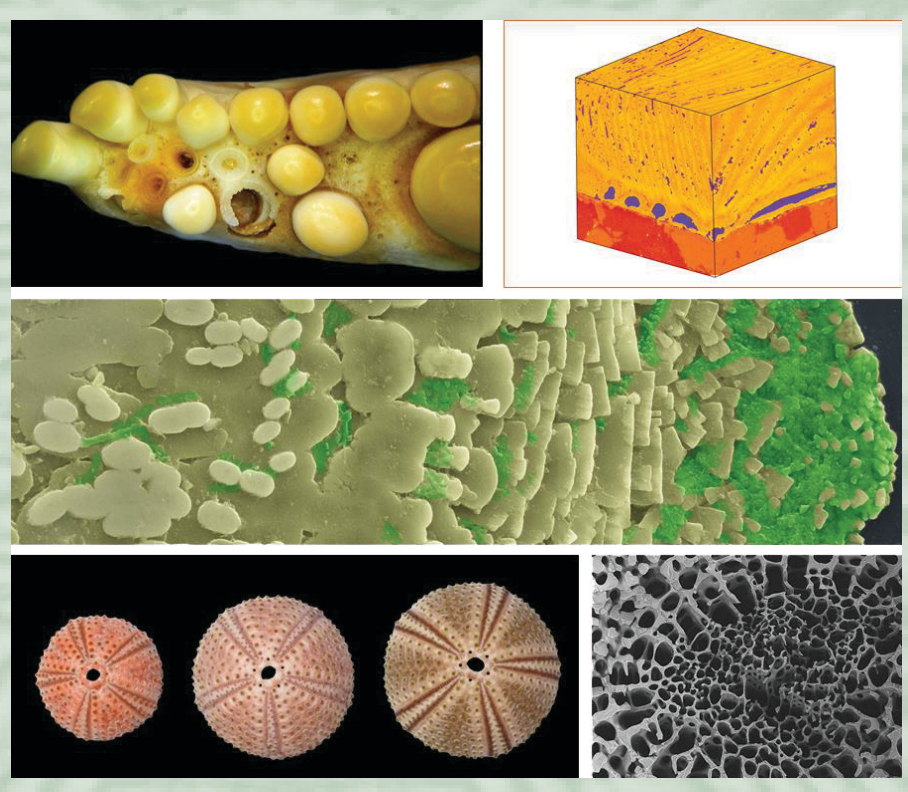

TTP TRANS TECH PUBLICATIONS 


\section{Key Engineering Materials}

ISSN 1013-9826

Founding Editor:

Fred H. Wöhlbier

Editors:

Erian A. Armanio

Yu Wing Mai

Golam M. Newaz

Editorial Advisory Board: see back inside cover

Aims and Scope:

„Key Engineering Materials“s specializes in rapid publication of thematically complete volumes from international conference proceedings and complete special topic volumes. We do not publish stand-alone papers by

"Key Engineering Materials" covers entire range of basic and applied aspects of the synthesis and research modelling, processing and application of advanced engineering materials.

Authors retain the right to publish an extended and significantly updated version in another periodical.

Indexing:

Indexed by Elsevier: SCOPUS www.scopus.com. Index

Copernicus Journals Master List www.indexcopernicus.com

Google Scholar scholar.google.com.

Cambridge Scientific Abstracts (CSA) www.csa.com

Inspec (IET, Institution of Engineering Technology) www.theiet.org.

SCImago Journal \& Country Rank (SN) WWw.scimagoj.co

Then mics (WoS), al

Internet:

The periodical is available in full text via www.scientific.net

Subscription Information:

34 Volumes: Vols. 663-696 (2010)

The subscription rate web access only is EUR 2400.00 per year,

for web + print EUR 3313.00 including postage/handling charges.

ISSN print 1013-9826 ISSN cd 1662-9809 ISSN web 1662-9795

\section{Trans Tech Publications Ltd}

Churerstr. 20 - 8808 Pfaffikon • Switzerland
Fax +41 (44) $9221033 \cdot$ e-mail: ttp@attp.net

http://www.ttp.net

\section{Key Engineering Materials}

ISSN 1013-9826

\begin{tabular}{|c|c|c|}
\hline Australia & Germany & Slovakia \\
\hline L. Chang (Sydney) & A.R. Boccaccini (Erlangen) & J. Dusza (Košice) \\
\hline Y.B. Cheng (Clayton) & G. Grathwohl (Bremen) & P. Šajgalík (Bratislava) \\
\hline C.H.J. Davies (Clayton) & H. Schmidt (Clausthal-Zellerfeld) & \\
\hline M. Hoffman (Sydney) & H. Schneider (Köln) & South Korea \\
\hline X.Z. Hu (Perth) & & S. Baik (Kyung-Buk) \\
\hline S.P. Lynch (Melbourne) & India & C.P. Hong (Seoul) \\
\hline B.H. O'Connor (Perth) & D. Chakravorty (Calcutta) & S.H. Hong (Daejeon) \\
\hline K. Xia (Melbourne) & B.V. Radhakrishna Bhat (Hyderabad) & \\
\hline M.X. Zhang (Queensland) & $\begin{array}{l}\text { S. Ray (Himachal Pradesh) } \\
\text { B.K. Sarkar (Calcutta) }\end{array}$ & $\begin{array}{l}\text { Spain } \\
\text { L. Esquivias (Sevilla) }\end{array}$ \\
\hline \multirow[t]{2}{*}{$\begin{array}{l}\text { Austria } \\
\text { R. Danzer (Leoben) }\end{array}$} & G.S. Upadhyaya (Kanpur) & A. Urena-Fernandez (Madrid) \\
\hline & Ireland & The Netherlands \\
\hline \multirow{2}{*}{$\begin{array}{l}\text { Belgium } \\
\text { J.R. Duflou (Leuven) }\end{array}$} & P. McHugh (Galway) & R.J. Fordham (Petten) \\
\hline & Israel & Turkey \\
\hline \multirow[t]{2}{*}{$\begin{array}{l}\text { Brazil } \\
\text { L. Salgado (São Paulo) }\end{array}$} & R. Fischer (Haifa) & H. Mandal (Eskisehir) \\
\hline & Japan & UK \\
\hline Canada & H. Hamada (Kyoto) & A. Hendry (Glasgow) \\
\hline S.V. Hoa (Montreal) & M. Iwasa (Osaka) & F.L. Riley (Leeds) \\
\hline P. Sullivan (Waterloo) & K. Kishimoto (Tokyo) & R. Taylor (Manchester) \\
\hline \multirow[t]{2}{*}{ Z.R. Wang (Toronto) } & M. Mitomo (Ibaraki) & \\
\hline & O. Nakamura (Osaka) & USA \\
\hline China P.R. & H. Sekine (Sendai) & R. Abbaschian (Gainesville) \\
\hline $\begin{array}{l}\text { C.C. Ge (Beijing) } \\
\text { C. Ge }\end{array}$ & K. Uematsu (Nagaoka) & D.H. Allen (College Station) \\
\hline $\begin{array}{l}\text { J.H. Gong (Beijing) } \\
\text { D. L Jiang (Shanghai) }\end{array}$ & & I.C. Clarke (California) \\
\hline D.L. Jiang (Shanghai) & New Zealand & I. Dutta (Monterey) \\
\hline $\begin{array}{l}\text { J.K. Kim (Hong Kong) } \\
\text { A. Xing (Zibo) }\end{array}$ & W. Gao (Auckland) & $\begin{array}{l}\text { W.W. Gerberich (Minneapolis) } \\
\text { E.J. Lavernia (Davis) }\end{array}$ \\
\hline $\begin{array}{l}\text { X. P. Xu (Xiamen) } \\
\text { X. }\end{array}$ & Portugal & S. Mall (Wright-Patterson AFB) \\
\hline L.M. Zhou (Hong Kong) & R.M. Almeida (Lisboa) & $\begin{array}{l}\text { R.O. Ritchie (Berkeley) } \\
\text { Selchar (Cincinnati) }\end{array}$ \\
\hline & & $\begin{array}{l}\text { J.A. Sekhar (Cincinnati) } \\
\text { J. Shackelford (Davis) }\end{array}$ \\
\hline \multirow{2}{*}{$\begin{array}{l}\text { Denmark } \\
\text { B.F. Sorensen (Roskilde) }\end{array}$} & Russia & J.E. Shelby (Alfred) \\
\hline & S.M. Barinov (Moscow) & A. Shukla (Kingston) \\
\hline \multirow{3}{*}{$\begin{array}{l}\text { Egypt } \\
\text { M.A. Taha (Cairo) }\end{array}$} & & W.O. Soboyejo (Princeton) \\
\hline & Serbia & R. Solecki (Storrs) \\
\hline & D. Uskoković (Belgrade) & J.M. Yang (Los Angeles) \\
\hline
\end{tabular}

M. Ignat (Saint Martin d'Hères) F. Thevenot (Saint-Etienne)

Singapore

C.Y. Yue (Nanyang)
Trans Tech Publications Ltd
Churerstr. 20 • 8808 Pfaffikon • Switzerland http://www.ttp.net




\section{Biomineralization: From Fundamentals to Biomaterials \& Environmental Issues}

Edited by Frédéric Marin Franz Brümmer Antonio Checa Gabriel Furtos Isidoro Giorgio Lesci Lidija Šiller 



\section{Biomineralization: From Fundamentals to Biomaterials \& Environmental Issues}

Special topic volume with invited peer reviewed papers only.

\section{Edited by}

Frédéric Marin, Franz Brümmer, Antonio Checa, Gabriel Furtos, Isidoro Giorgio Lesci and Lidija Šiller

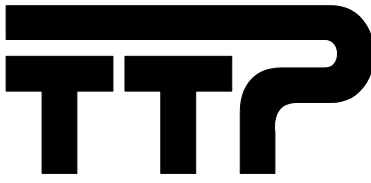


Copyright $\odot 2015$ Trans Tech Publications Ltd, Switzerland

All rights reserved. No part of the contents of this publication may be reproduced or transmitted in any form or by any means without the written permission of the publisher.

Trans Tech Publications Ltd

Churerstrasse 20

$\mathrm{CH}-8808$ Pfaffikon

Switzerland

http://www.ttp.net

Volume 672 of

Key Engineering Materials

ISSN print 1013-9826

ISSN cd 1662-9809

ISSN web 1662-9795

Full text available online at $h t t p: / / w w w . s c i e n t i f i c . n e t$

Distributed worldwide by

Trans Tech Publications Ltd

Churerstrasse 20

$\mathrm{CH}-8808$ Pfaffikon

Switzerland

Fax: +41 (44) 9221033

e-mail: sales@ttp.net and in the Americas by

Trans Tech Publications Inc.

PO Box 699, May Street

Enfield, NH 03748

USA

Phone: +1 (603) 632-7377

Fax: +1 (603) 632-5611

e-mail: sales-usa@ttp.net

printed in Germany 


\section{It is a fine thing to be honest, but it is also very important to be right (Winston Churchill). Science never solves a problem without creating ten more (George Bernard Shaw). If the facts don't fit the theory, change the facts (Albert Einstein).}

\section{PREFACE}

The present book deals with biomineralization, i.e., the process by which living organisms - from bacteria to whale - synthesize minerals. It represents the final publication of the COST Action TD0903, more simply nicknamed Biomineralix. This Action, which was set up under the auspice and financial support of the COST organization (European COoperation in Science and Technology) in November 2009, ended its activity in May 2014, after a fourand half years of intense scientific activity.

Let us briefly remind how things were initiated: the idea of structuring a European consortium focused on biomineralization was already floating in the air, since the beginning of the years 2000 and resulted from constructive discussions between two of us (D. Medakovic, F. Marin) in the course of 2003 and 2004, and from different bilateral collaborations established by the Croatian team (D. M.) with Italian and Slovenian partners. However, the true founding act was the 'shaping' of the full-length proposal by the Croatian partner, an action that gave the decisive push without which no 'nuclei would have germinated and grown' (after all, we deal with mineral, don't we?). Following the 'grand oral' exam in front of the COST commission in Brussels, the positive evaluation of the proposal in March 2009 and its subsequent acceptance by the COST Office, the Biomineralix network was constituted in the fall of 2009, with eight partner countries. To our knowledge, this was the first COST network of this type, i.e., entirely focused on biomineralization. Its main objective was to bring together research groups with very different expertise throughout Europe and elsewhere, to stimulate new, innovative and high-impact interdisciplinary research in this very peculiar field. Because of its chemistryoriented nature and of potential applications in industry ensuing from the network's activity, our consortium was administered by the Chemistry and Molecular Sciences and technologies domain (CMST), one of the nine scientific domains of the COST organization, covering all aspects of sciences and technologies in Europe. However, due to its multidisciplinary nature, our network belonged also to the tenth 'Trans-Disciplinary' (TD) domain.

This book presents a collection of papers - reviews, research articles, technical notes that reflect some of the research directions developed during four and half years of activity. In short, it gives a 'flavour' of some topics, tackled by the network, in particular topics related to biological and proteomic research in biomineralization, to the advanced analysis and characterization of biomineralizations and biomaterials, to the environmental bio-monitoring by biominerals, to researches on novel biomaterials and fossil biominerals.

This network would not have worked properly without the help and contribution of keypeoples: first of all, we would like to thank Lucia Forzi, the Scientific Officer of the COST Office, in charge of many actions within the CMST domain. Lucia was, from the beginning to the end, the vigilant guardian of our consortium, reminding us some rules of functioning that we tended to forget. We also include in our acknowledgments the other members of the COST Office: Valentina Vignoli, Svetlana Voinova, Andrea Tortajada, Monica Dietl, Marie-Eve Hastir, Jacob Riambau Santacana, Kent Hung, Erwan Arzel. We also thank Dieter Schinzer, 
the Chair of the COST CMST domain and all the CMST evaluators, present at the successive Annual Progress Conferences.

We also warmly thank Professor Jan Reedijk (Leiden University, The Netherlands) who was our COST rapporteur from the beginning, and carefully advised us, during our successive management committee meetings, on how to conduct properly the network. We are also grateful to Professor Maggie Cusack (University of Glasgow, UK) who took time, as external evaluator, to appraise our action.

We acknowledge all the numerous guest researchers (we cannot cite them all) that were invited to give extended talks during our six consecutive international workshops. All the local organizers of these workshops are also thanked for setting up nice conferences including social activities.

Last but not least, we thank all the colleagues who jumped into our 'COST Action boat' and contributed to feed its engine via fruitful discussions, posters, oral presentations and scientific interactions. Are thanked all the early-stage researchers, particularly those who were active in the network by 'experimenting' short-term scientific missions and by showing their results during subsequent yearly workshops.

And at the very last, we would like to thank the contributors of this book, and our editor at Trans Tech Publications, Thomas Wohlbier, and his team.

Frédéric Marin, Lidija Šiller, Franz Brümmer, Isidoro Giorgio Lesci, Antonio Checa and Gabriel Furtos 

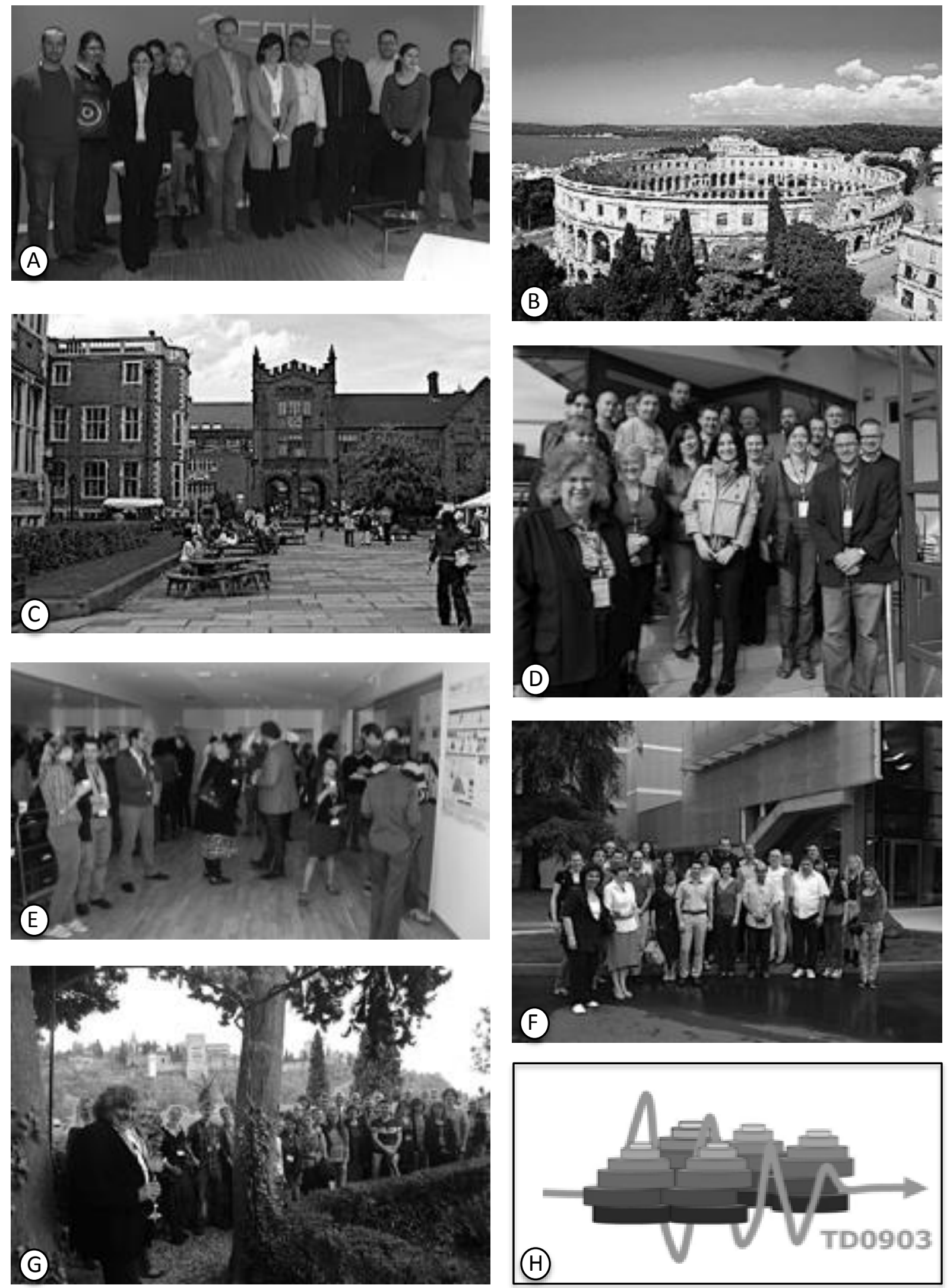

Successive meetings of the Cost Action TD0903 Biomineralix. A: kickoff meeting, Brussels (BE); B: Pula (HR); C: Newcastle (UK); D: Cluj Napoca (RO); E: Aarhus (DK); F: Bologna (IT); G: Granada (ES); H: logo of the COST Action TD0903 'Biomineralix. 


\section{Scientific editorial board}

\section{Main editor:}

Frédéric MARIN, vice- Chair (2009-2011) and Chair (2012-2014) of the COST Action.

Unité Mixte de Recherche CNRS 6282 Biogéosciences, Université de Bourgogne, Dijon, France.

\section{Co-editors:}

\section{Franz BRÜMMER,}

Institut für Biomaterialien und biomolekulare Systeme, Abtl. Zoologie, Universität Stuttgart, Stuttgart, Germany.

\section{Antonio G. CHECA,}

Departamento de Estratigrafía y Paleontología, Facultad de Ciencias, Universidad de Granada, Granada, Spain.

\section{Gabriel FURTOS,}

Department of Dental Composite Materials, "Raluca Ripan" Institute of Research in Chemistry \& Faculty of Chemistry and Chemical Engineering, Babes-Bolyai University, Cluj-Napoca, Romania.

\section{Isidoro Giorgio LESCI,}

Laboratory of Environmental and Biological Structural Chemistry (LEBSC), Dipartimento di Chimica "G. Ciamician", Università di Bologna, Bologna, Italy.

\section{Lidija SILLER,}

School of Chemical Engineering and Advanced Materials, Newcastle University, Newcastle, United Kingdom. 


\section{Financial support}

This publication is supported by COST (European Cooperation in Science and Technology).

COST (European Cooperation in Science and Technology) is a pan-European intergovernmental framework. Its mission is to enable break-through scientific and technological developments leading to new concepts and products and thereby contribute to strengthening Europe's research and innovation capacities.

It allows researchers, engineers and scholars to jointly develop their own ideas and take new initiatives across all fields of science and technology, while promoting multi-and interdisciplinary approaches. COST aims at fostering a better integration of less research intensive countries to the knowledge hubs of the European Research Area. The COST Association, an International not-for-profit Association under Belgian Law, integrates all management, governing and administrative functions necessary for the operation of the framework. The COST Association has currently 36 Member Countries.

COST web site : http://www.cost.eu
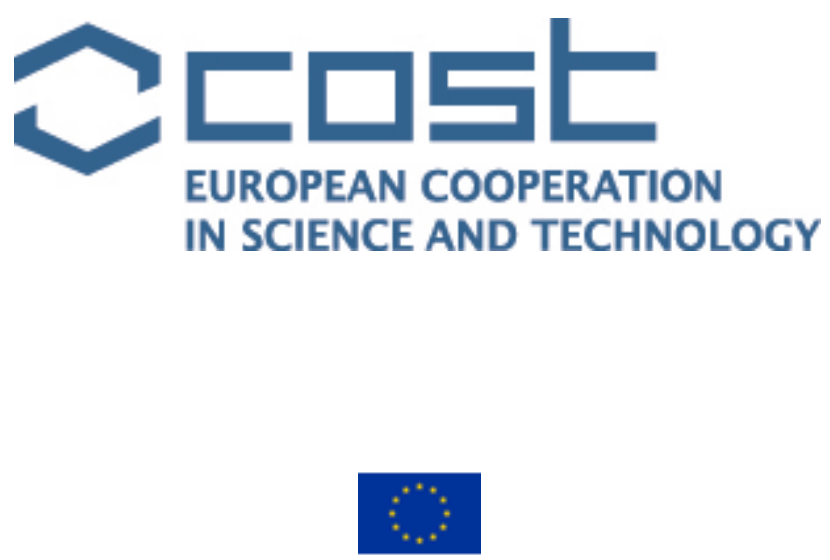

COST is supported by the EU Framework Programme Horizon 2020 


\section{Table of Contents}

Preface $\quad$ V

Editorial Board \& Financial Support viii

\section{Introduction}

Biomineralix (COST Action TD0903), 2009-2014: An Overview

F. Marin, D. Medaković and F. Brümmer

\section{Chapter 1: From Microbes to Molluscs: Non-Vertebrate Models in} Biomineralization

Experimental Modeling of Bacterially-Induced Ca Carbonate Precipitation: New Insights on Possible Mechanisms

I.A. Bundeleva, L.S. Shirokova, E.I. Kompantseva, P. Bénézeth, B. Ménez, F. Marin and O.S. Pokrovsky

Biomineralization in Ciliates

M.L. Lemloh

Single Nanogranules Preserve Intracrystalline Amorphicity in Biominerals

S.E. Wolf, C. Böhm, J. Harris, M. Hajir, M. Mondeshki and F. Marin.

Crystallography and Textural Aspects of Crossed Lamellar Layers in Arcidae (Bivalvia, Mollusca) Shells

Í. Almagro, P. Drzymała, A.B. Rodríguez-Navarro, C.I. Sainz-Díaz, M. Willinger,

J. Bonarski and A.G. Checa

Pore Structures in the Biomineralized Byssus of Anomia simplex

S. Frølich, H. Leemreize, J.S. Thomsen and H. Birkedal.

Natural Pearls

A. Vasiliu

The Transport System of Nacre Components through the Surface Membrane of

Gastropods

E. Macías-Sánchez, A.G. Checa and M.G. Willinger.

To Infer the early Evolution of Mollusc Shell Microstructures

M.J. Vendrasco, A.B. Rodríguez-Navarro, A.G. Checa, L. Devaere and S.M. Porter.... 


\section{Chapter 2: Biochemistry, Molecular Biology and Proteomics for Studying Biominerals}

Mytilus galloprovincialis Carbonic Anhydrase II: Activity and cDNA Sequence

Analysis

D. Pavičić-Hamer, A. Baričević, M. Gerdol and B. Hamer.

Carbonic Anhydrase and Metazoan Biocalcification: A Focus on Molluscs

N. Le Roy, D.J. Jackson, B. Marie, P. Ramos-Silva and F. Marin

Unveiling the Evolution of Bivalve Nacre Proteins by Shell Proteomics of

Unionoidae

B. Marie, J. Arivalagan, L. Dubost, S. Berland, A. Marie and F. Marin....

Characterization of the Teeth Skeletal Matrix from Arbacia lixula

J.M. Kanold, F. Immel, A. Marie, L. Plasseraud, G. Alcaraz, F. Brümmer and F. Marin

Proteins as Functional Units of Biocalcification - An Overview

P. Ramos-Silva and F. Marin...

Data Mining Approaches to Identify Biomineralization Related Sequences

F. Immel and F. Marin

Staining SDS-PAGE Gels of Skeletal Matrices after Western Blot: A Way to

Improve their Sharpness

F. Marin, F. Immel, N. Trinkler and D. Gaspard....

Thermal Stability of Nacre Proteins of the Polynesian Pearl Oyster: A Proteomic Study

A. Parker, F. Immel, N. Guichard, C. Broussard and F. Marin

\section{Chapter 3: Biomaterials for Biomedical Application}

Synthetic Biomimetic HA Composite Scaffolds for the Bone Regenerative Medicine Using CAD-CAM Technology

I.G. Lesci, L. Ciocca, O. Mezini and N. Roveri

Properties and Characterization of Chitosan/Collagen/PMMA Composites

Containing Hydroxyapatite

A. Sionkowska, B. Kaczmarek, P. Trokowska and I. Antoniac

Structure and Interactions in Chitosan Composites

K. Lewandowska, A. Sionkowska, G. Furtos, S. Grabska and M. Michalska.

Biocomposites for Orthopedic and Dental Application

G. Furtos, L. Silaghi-Dumitrescu, K. Lewandowska, A. Sionkowska and P. Pascuta

Bioceramics and Biocomposites from Marine Sources

I. Antoniac, G.I. Lesci, A.I. Blajan, G. Vitioanu and A. Antoniac. 276 


\section{Chapter 4: Biominerals as Sentinels for Environmental Studies}

Environmental Characterization of Lake Ecosystems Located in Serbo Macedonian Massif (FYRM)

T. Dolenec, T. Serafimovski, S. Lojen, M. Dolenec, G. Tasev, S. Kramar, N. Rogan

Šmuc and P. Vrhovnik

Sulphur-Containing Compounds as a Response in Sea Urchins Exposed to Alkylated Silicon Nanocrystals and $\mathrm{SiO}_{2}$-Coated Iron Oxide Nanoparticles

L. Šiller, S. Piticharoenphun, M.L. Lemloh, B.R. Horrocks, B. Kaulich,

A. Gianoncelli, M.R.C. Hunt, F. Brummer and D. Medaković....

Trace Metals in Fish Biominerals as Environmental Indicators: Handheld XRF

Analyses

D. Medaković, T. Dolenec, D. Karlović, P. Vrhovnik, N. Rogan Šmuc, S. Rončević,

L. Pitarević-Svedružić and M. Dolenec

Heavy Metals in Mollusc Shells: A Quick Method for their Detection

A. Osuna-Mascaro, T. Cruz-Bustos, B. Marie, A. Checa and F. Marin .

Keyword Index

Author Index 



\title{
Environmental characterization of lake ecosystems located in Serbo Macedonian massif (FYRM)
}

\author{
Tadej Dolenec ${ }^{1, a}$, Todor Serafimovski ${ }^{2, b}$, Sonja Lojen ${ }^{3, c}$, Matej Dolenec ${ }^{1, d}$, \\ Goran Tasev, e, Sabina Kramar $^{4, \mathrm{f}}$, Nastja Rogan Šmuc ${ }^{1, \mathrm{~g}}$, Petra Vrhovnik ${ }^{1, \mathrm{~h}}$ *
}

${ }^{1}$ Faculty of Natural Sciences and Engineering, University of Ljubljana, Department of Geology, Aškerčeva 12, 1000 Ljubljana, Slovenia

${ }^{2}$ Faculty of Natural and Technical Sciences, "Goce Delčev" University, Goce Delčev 89, MK-2000, Štip, Former Yugoslav Republic of Macedonia

${ }^{3}$ Institute Jožef Štefan, Jamova cesta 39, 1000 Ljubljana, Slovenia

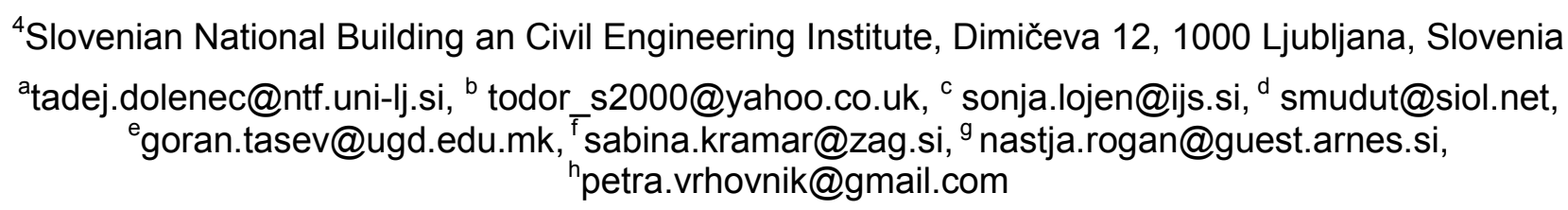

Keywords: Mineralogy, geochemical composition, isotopic signature, Anodonta cygnea, Lake Dojran sediments, Lake Kalimanci sediments, Former Yugoslav Republic of Macedonia (FYRM), Vimba melanops, Rana temporaria, Rutilus rutilus dojranensis.

\begin{abstract}
This paper presents the mineralogical, geochemical and isotopic characteristics of recent lacustrine sediments, of Anodonta cygnea shells and of fish species Rutilus rutilus dojranensis from the Lake Dojran (FY Republic of Macedonia, southern part of the Serbo-Macedonian Massif (SMM)), which provide indirect evidence regarding biomineralization and calcification processes as well as various geological problems. Environmental pollution can seriously impair physiological functions such as the secretion of carbonate material into the shells. For comparison, sediments and fish species Vimba melanops from the Lake Kalimanci, located in northern part of the SMM, were also included into the study.

X-ray powder diffraction (XRD), inductively coupled plasma mass spectrometry (ICP-MS) and carbon (C) and oxygen (O) stable isotope analyses were performed, and thereupon enrichment factor (EF) values were calculated. The XRD results revealed close association of sediment mineralogy with the prevailing metamorphic, volcanic and igneous rocks of the region surrounding both lakes (Dojran and Kalimanci). According to the EF value results, surficial Lake Dojran sediments are slightly enriched with $\mathrm{Co}, \mathrm{Cr}, \mathrm{Cu}, \mathrm{Pb}$, and $\mathrm{Zn}$, moderately enriched with $\mathrm{Au}$, Ni and $\mathrm{Sb}$, moderately to severely enriched with $\mathrm{Au}$, severely enriched with $\mathrm{Sb}$ and extremely enriched with As. This elemental enrichment originates from various geogenic (geological background and polymetallic mineralization) and anthropogenic (tourism, traffic, coatings, untreated wastewater discharge and agrochemicals) sources. Calculated EF revealed that surficial sediments from Lake Kalimanci are extremely enriched with $\mathrm{Pb}, \mathrm{Zn}$, and $\mathrm{Cd}$, meanwhile $\mathrm{As}$ and $\mathrm{Cu}$ shows very severe enrichment. Comparing to Lake Dojran, calculated EF is much higher in Lake Kalimanci than in Dojran.

Stable isotope signature results showed that Lake Dojran sediments were strongly influenced by evaporation effect. Their $\delta^{18} \mathrm{O}$ values range from -5.60 to $+1.49 \%$ and the $\delta^{13} \mathrm{C}_{\mathrm{VPDB}}$ composition range from -6.45 to $-1.65 \%$. Shells of $A$. cygnea are mainly composed of mineral aragonite and their $\delta^{18} \mathrm{O}$ values varies between $0.43 \%$ and $+1.94 \%$, and $\delta{ }^{13} \mathrm{C}_{\mathrm{VPDB}}$ between -2.48 to $-1.72 \%$. $\delta^{18} \mathrm{O}$ signature in shells might be explained by precipitation of the carbonate from isotopically heavier oxygen lake water. The unusually high skeletal oxygen suggests calcification at elevated temperature and evaporation. Analyses also identify particularly high levels for $\mathrm{Cr}, \mathrm{Hg}, \mathrm{Ni}$ and $\mathrm{Pb}$ in fishes ( $V$. melanops) and frog (Rana temporaria) samples from Lake Kalimanci with mean values $\left[\mu \mathrm{gkg}^{-1}\right]: 1090-6.5,339-117,567-5100$ and $1127-435$, respectively. Meanwhile, the
\end{abstract}


contents of $\mathrm{Cr}, \mathrm{Hg}, \mathrm{Ni}$ and $\mathrm{Pb}$ in fishes samples (R. rutilus dojranensis) from Lake Dojran are a bit lower $\left[\mu \mathrm{gkg}^{-1}\right]: 2320,1690,700$ and 50.

\section{Introduction}

Lakes represent some of the most versatile and unique ecosystems on Earth, but unfortunately they are also readily affected by various anthropogenic activities [1]. Since lakes are mostly closed or nearly closed systems, lake sediments can be treated as the final recipients of the results of anthropogenic activity within the lake-basin area. Consequently, they operate as both carriers and storage sinks for contaminants, thus reflecting the history of long-term geogenic or anthropogenic impacts [2-5]. Contaminants, especially trace elements and metalloids, are a group of pollutants with high ecological significance in aquatic ecosystems. Trace elements do not exist in solid phases in water bodies, instead accumulating mainly in suspended particulates or in sediment material [6-8]. Metals/metalloids found in aquatic sediments may be natural or man-made in origin; weathering of soils/rocks and atmospheric deposition are known geogenic sources, while the discharge of agricultural, municipal, residential and industrial waste products from surrounding environments into water bodies has been determined as the main anthropogenic source [5-6,8-9].

One of the major environmental problem dealing with trace elements (metals and metalloids) is that they can be absorbed into living beings and, consequently, that they are toxic in even low concentrations. Not much is known about biochemical responses to trace elements by bivalves $[10,11]$. Trace elements in different animal species, such as bivalves and fishes, can cause difficulties in development, growth, mortality and also reproduction [12] and can be also present in shell and most likely affect biomineralization processes. Furthermore, provided data could be used for interpretations regarding alterations in biomineralization processes influenced by environmental changes.

Over the last few decades, a number of geochemical studies have focused on lake sediments with the aim of evaluating the extent of environmental contamination [13-17].

Lake Dojran, located in the SE of the FYRM, is situated on the border between FYRM and the Republic of Greece. Geothermal processes and polymetallic mineralization in the lake Dojran catchment area could potentially have conferred uniquely beneficial properties on the dark mud lake sediments, possibly such that the latter could be perceived as having healing powers (i.e. peloids) [18]. Unfortunately, information regarding the environmental status of Lake Dojran sediments is very scarce and unconfirmed [19].

Lake Kalimanci lies in NE part of FYRM, near the border with Republic of Bulgaria. Both lakes (Dojran and Klaimanci) are a part of Serbo-Macedonian Massif (SMM), which extends from northern border with Republic of Serbia to the southern border with Republic of Greece, and is mainly composed by igneous and metamorphic rocks. In the vicinity of Lake Kalimanci can be found $\mathrm{Pb}-\mathrm{Zn}$ ore deposits as well as active mines with its belonging tailing dams. Lake Kalimanci environment was heavily affected by a failure of Sasa tailings dam, therefore increased amounts of potentially toxic (trace) elements are expected in lake sediments.

The main objective of the research was to characterize studied freshwater environments to reveal the growth patterns of biominerals and possible changes in metabolic pathways in biomineralizing organisms under various environmental influences. Additionally, some other objectives were determined as follows:

- to evaluate the elemental content and distribution in Lake Dojran and Lake Kalimanci sediments,

- to define the anthropogenic versus natural contribution to Lake Dorjan and Lake Kalimanci sediment trace element concentrations,

- to provide isotopic characteristic of sediments and Anodonta cygnea shells originating from Lake Dojran, and

- to evaluate the pollution status of Lake Dojran and Lake Kalimanci environment, to reveal the influences of trace elements on biomineralization of freshwater shells. 


\section{Materials and methods}

\subsection{Description of the study sites and geological characteristics}

Lake Dojran, a natural wonder with a rich cultural heritage, is located in the SE of the FYRM, on the border between FYRM and the Republic of Greece (Fig. 1). Lying at an altitude of $148 \mathrm{~m}$ a.s.l., the lake has a mean depth of $6.7 \mathrm{~m}$ and a surface area of $43.10 \mathrm{~km}^{2}, 66 \%$ of which belongs to the territory of the FYRM. Lake catchment area is about $120 \mathrm{~km}^{2}$ (mainly from the N and NE, where the Bjelasica mountains are situated). Lake Dojran is elliptical in shape, with a N-S elongation $8.9 \mathrm{~km}$ in length and $7 \mathrm{~km}$ in width. In the northern part of the lake there are a few small groundwater sources. Due to high water outflow (irrigation system) in the south, the Macedonian Government decided to build water-feeding system into the lake, which consists of wells system in river Vardar (near city Valandovo), $20 \mathrm{~km}$ away from the Lake Dojran. All of them are combined into one inflow with capacity of 650-800 1/s, near the city of Novi Dojran. The Dojran area was and still is an important agricultural and tourist province [19]. Agricultural and tourism activities around the lake resulted in enhanced agrochemicals, landfill leachate and municipality discharges into the lake and increased traffic effects.

Lake Kalimanci is located in the east of FYR Macedonia (Fig. 1). It is an artificial lake, with its longest length $4 \mathrm{~km}$ and greatest width $0.3 \mathrm{~km}$, and a maximum depth of 80 meters. The surface area of the lake is $4.23 \mathrm{~km}^{2}$ and it accumulates approximately 127 million $\mathrm{m}^{3}$ of water. Lake Kalimanci is surrounded on the eastern side by uncultivated ground, with no industry or households. Meanwhile, in the western part a main road runs parallel to the lake and serves as the main connection between the agriculturally important Kočani Field, Sasa $\mathrm{Pb}-\mathrm{Zn}$ Mine, and the Bulgarian border.

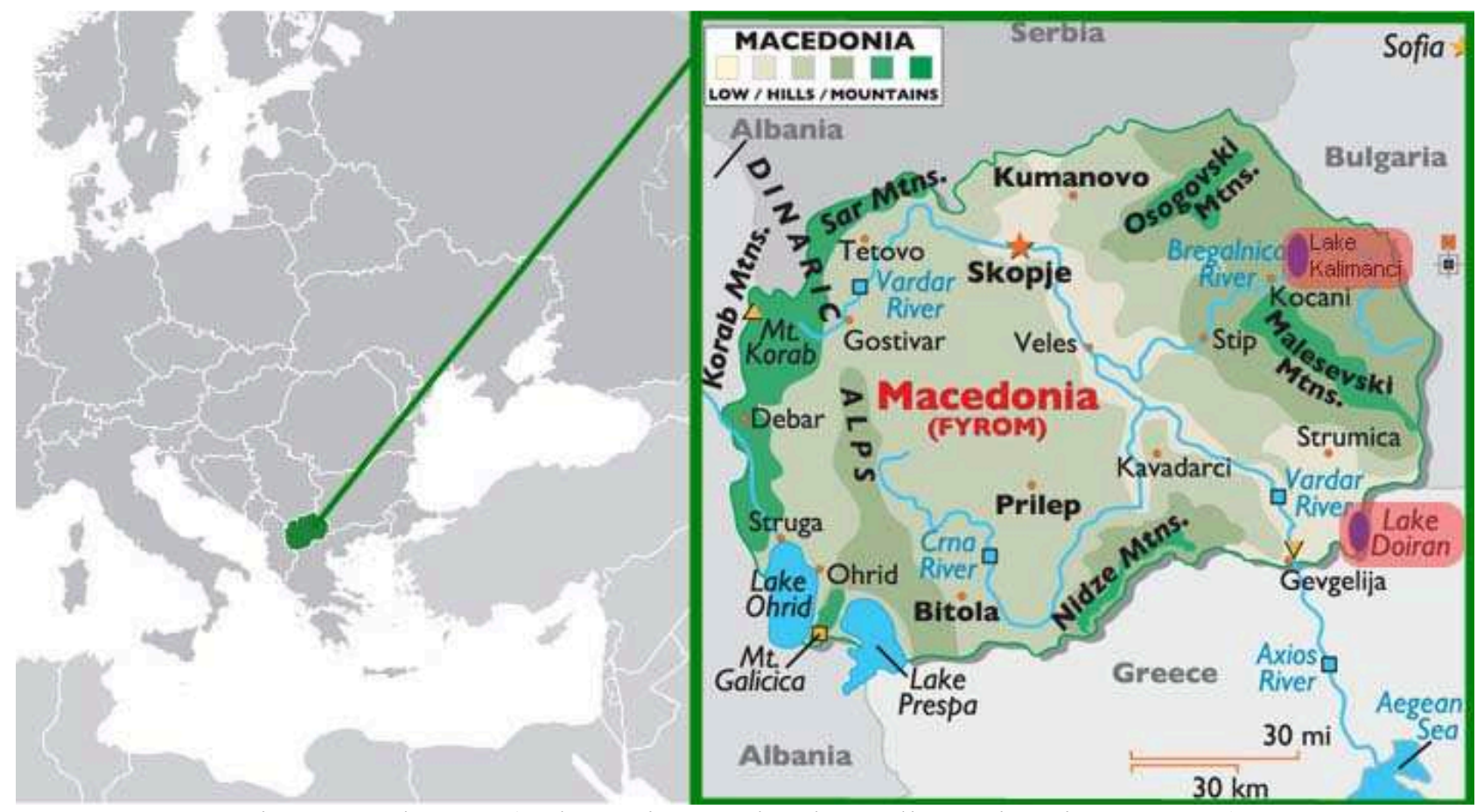

Fig. 1: Study area (Lake Dojran and Lake Kalimanci region, FYRM).

Lake Dojran is located in the Dojran graben, the tectonic border between metamorphic rocks of the SMM and volcanic/sedimentary rocks of the Vardar zone. Development of the Dojran graben is related to the neotectonic movement during the Neogene which were followed by volcanic and post-volcanic activities. Precambrian and Palaeozoic metamorphic rocks (gneisses, shales, amphibolies and marbles) of the SMM currently comprise the NE of the study site, together with intrusions of Bjelasica granites and basic intrusions of gabbro. Serpentinites can be found in the eastern part of the massif, while the border of the SMM with the Vardar zone is composed of granite porphyries, metarhyolites and metamorphic pyroclastites. The region SW of the lake is 
represented by four main lithologies: Permian to Triassic metamorphic sedimentary and volcanic rocks, and Tertiary Q conglomerates and volcanic rocks (trachytes and rhyolites) (Fig. 2). Polymetallic mineralization with chalcopyrite, pyrite, bornite and gold is located in the contact between muscovite gneisses and amphibolite shales, whereas a pyrite-arsenopyrite-gold polymetallic association forms part of basic rocks [18]. While Lake Kalimanci is also a part of the SMM, the same geological setting of researched area was determined there. The main difference that should be exposed is that in the vicinity of Lake Kalimanci is located a large $\mathrm{Pb}-\mathrm{Zn}$ ore deposit, as well as an active mine with accompanying tailings dam which is directly connected to the Lake Kalimanci through River Kamenica.

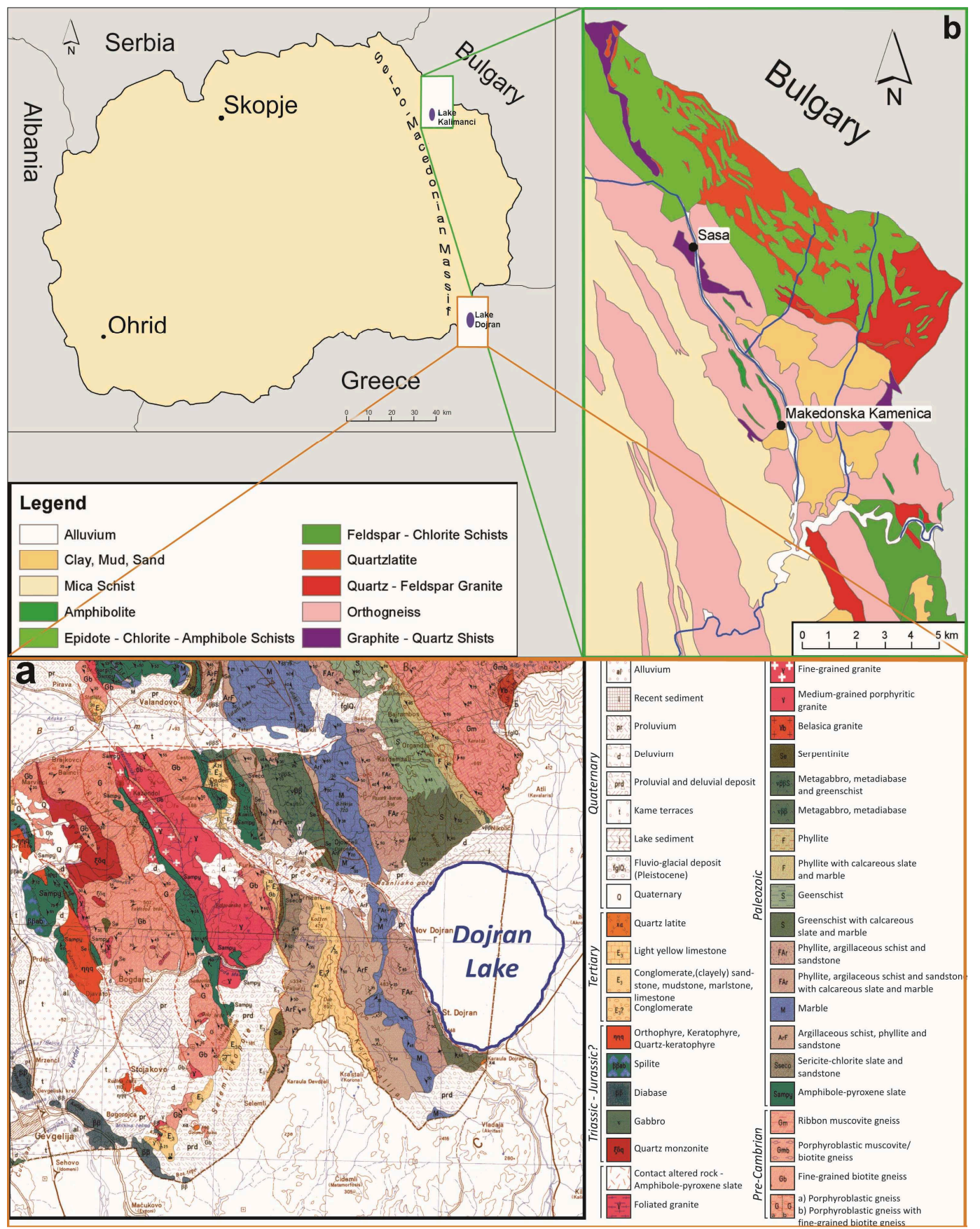

Fig. 2: Geological composition of research area ( $\mathrm{a}$ - Lake Dojran surroundings, $\mathrm{b}$ - Lake Kalimanci

\subsection{Sampling} surroundings).

Sampling of lake sediments was carried out on six sampling locations (D1, D2, D3, D4, D5 and D6) across Lake Dojran (FYRM) are shown in Fig. 3a. Samples were precisely collected with the push plastic corers (tube $20 \mathrm{~cm}$ long with a $10 \mathrm{~cm}$ internal diameter), tightly packed into pre- 
cleaned plastic bags and stored in the laboratory at $4{ }^{\circ} \mathrm{C}$. Samples were sectioned into three $5 \mathrm{~cm}$ depth slices: $0-5 \mathrm{~cm}$ (6 locations), $5-10 \mathrm{~cm}$ (2 B locations) and $10-15 \mathrm{~cm}$ (2 C locations).

The 31 surficial sediment samples from eight profiles along Lake Kalimanci (Fig. 3b) were collected using plastic corers, $10 \mathrm{~cm}$ long, with $10 \mathrm{~cm}$ internal diameter. They were then packed into plastic bags and stored in the laboratory at $4^{\circ} \mathrm{C}$.

Samples from both lakes were prevailingly composed of sand, silt and clay. They were dried at $50{ }^{\circ} \mathrm{C}$ for $48 \mathrm{~h}$, before being sieved through a $0.315 \mathrm{~mm}$ polyethylene sieve in order to remove molluscan remains and other organic debris. Finally, the samples were homogenized using a mechanical agate grinder into a fine powder $(<63 \mu \mathrm{m})$ for subsequent analyses.

Anodonta cygnea shells were gathered by dragging from Lake Dojran clay bottom. Shells were randomly collected and stored in plastic tanks with natural lake water and temperature similar to natural conditions. Bodyweight of Anodonta cygnea samples was up to $200 \mathrm{~g}$. The shell of Anodonta cygnea was selected: it represents a good model to study biomineralization processes because it possesses large volume compartments with easy access to their organic matrices. In these shells, biomineralization occurs in two different compartments, each with specific biological fluid (haemolymph and extrapallial fluid) which are involved in mineral production at the mineral concretions (microspherules) level [11,20].

To collect the fish samples, fishing was performed during late afternoon towards the end of the fishing season in November 2010 with the help of professional local fisherman, as suggested in literature [21]. Fishes were caught in both lakes (two samples at each profile), afterwards they were stored in a container, cooled on crushed ice, and brought to the laboratory for further analysis. The fishes were sectioned, and all non-edible parts (e.g., bones, intestine, gills, fins, etc.) were removed so that only soft tissues were freeze-dried (for at least $72 \mathrm{~h}$ ) until a plateau weight was reached. Dried samples were homogenized and crushed to a fine powder by grinding in an agate mortar. The same procedure was used for frog collection around the Lake Kalimanci.

Caught fishes and frog species were determined as follows: Lake Kalimanci - Vimba melanops (fishes) and Rana temporaria (frogs); Lake Dojran - Rutilus rutilus dojranensis (fishes)
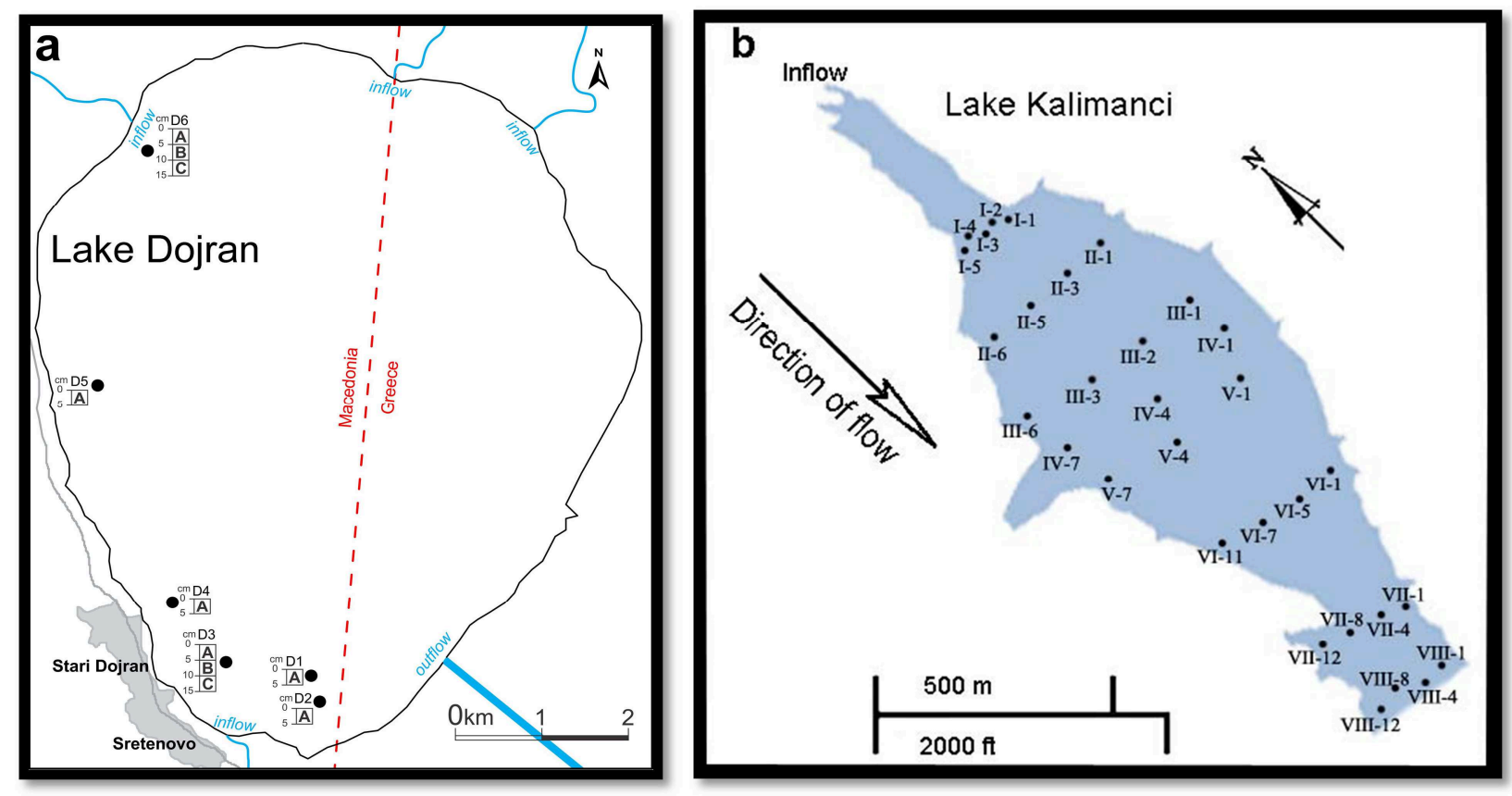

Fig. 3: Sampling locations across Lake Dojran (a) and Lake Kalimanci (b)

\subsection{Methods}

An amount of sample was roasted at $1000{ }^{\circ} \mathrm{C}$ to detect the loss on ignition (LOI), while sediment $\mathrm{pH}$ was measured in deionized water with a $1: 2$ soil/solution ratio after equilibration for 15 min [22]. Total carbon, content were analysed by LECO Carbon-Sulfur analyser in a certified commercial Canadian laboratory (Acme Analytical Laboratories). 
In order to define detailed mineralogical and elemental characteristics of sediment samples, X-ray powder diffraction (XRD) and ICP analyses were employed. Shells mineralogical composition was defined by X-ray powder diffraction (XRD) analysis, as well.

The mineral composition of the sediment samples was determined via X-ray powder diffraction using a Philips PW3710 X-ray diffractometer equipped with $\mathrm{Cu} \mathrm{K} \alpha$ radiation and a secondary graphite monochromator. Data were collected at $40 \mathrm{kV}$ and a current of $30 \mathrm{~mA}$ in a range from 2 to $70^{\circ} 2 \theta$, at a speed of $3.4 \mathrm{o} / \mathrm{min}$.

All surficial sediments were measured for their detailed geochemical composition in an accredited commercial Canadian laboratory (Acme Analytical Laboratories, Vancouver, B.C., Canada). Total abundances of major elements and trace elements were determined by ICP-emission spectrometry following lithium metaborate/tetraborate fusion and dilute nitric digestion. In addition, a separate sample was digested in Aqua Regia and analyzed via ICP Mass Spectrometry to report on precious and base metal content.

Duplicate samples and blanks were also included to ensure the accuracy of all analytical methods employed. Analytical precision and accuracy were better than $\pm 5 \%$ for the investigated elements.

Additionally, for $\mathrm{C}$ and $\mathrm{O}$ isotopic analysis, samples were obtained as a split of powder prepared for abovementioned analysis. In order to speed up the reaction time and to ensure complete reaction of carbonates, powdered samples were prepared by overnight digestion in excess $100 \%$ phosphoric acid at $50^{\circ} \mathrm{C} . \mathrm{CO}_{2}$ gas released during acid treatment was cryogenically cleaned and analyzed for carbon and oxygen isotopic composition on a Varian MAT 250 mass spectrometer. All investigated samples were analyzed in duplicate or triplicate. The $\delta^{13} \mathrm{C}$ values were normalized assuming IAEA-CO- 1 standard on the VPDB scale and $\delta^{18} \mathrm{O}$ values were normalized according to VPDB and SMOW standards. The analytical precision, based on multiple analysis of an internal laboratory standard, was $\pm 0.05 \%$.

All fishes samples were analyzed for 57 elements (major, minor, trace and REEs) at an accredited commercial laboratory, Act Labs (Activation Laboratories Ltd., Ancaster, Ontario, Canada in year 2011), using inductively coupled plasma mass spectrometry (ICP/MS) and microwave digestion. Dry, unwashed samples were digested in Aqua Regia solution 3/1 (v/v) $(\mathrm{HNO} 3+3 \mathrm{HCl})$ at $95^{\circ} \mathrm{C}$ for two hours. Resultant sample solutions were then diluted and analyzed on a Finnegan Mat Element 2 High Resolution ICP/MS (HR-ICP/MS). The quality of the analyses was monitored by comparison to the standard materials NIST $1575 \mathrm{a}$, NIST 1643e and SLRS-5 provided by Act Labs and the measurements of four samples were repeated. Besides Act Lab quality control, also our own standard MP-STD-011, and two standards prepared and provided by the International Atomic Energy Agency, Vienna (IAEA) - IAEA-407 and by National Research Council Canada - DORM-3 were sent to Act Labs for geochemical analysis as well. Our control standard MP-STD-011 is wild dogfishes soft tissue, which was analyzed many times by different techniques (ICP/MS, HR-ICP/MS, ICP/AES and XRF). The results indicated a good agreement between the certified and observed values. For reaching the best control, measurements were repeated on all fishes samples and three standards (MP-STD-011, IAEA-407, DORM-3) using Xray fluorescence (XRF) and inductively coupled plasma atomic emission spectroscopy (ICP-AES). The standard deviations of the means observed for the abovementioned certified materials were 1-6 $\%$.

\subsection{Statistical analysis}

To explore the elemental associations and thus origins of the analyzed elements in the Lake Dojran sediments, Pearson R correlation analyses were performed to all samples. Critical values of the correlation coefficient (r) 0.81 at $\mathrm{p} \leq 0.05$ were considered highly significant. Principal component analysis (PCA) based on a covariance matrix were used to examine variation in the measured parameters between locations. The basic statistical parameters for each element and the statistical calculations mentioned above were performed using the software programs Statistica VII and Grapher 8.0. 


\subsection{Enrichment factor}

The enrichment factor (EF) is an environmental index indicating the level of sediment environmental contamination. It was employed to estimate possible anthropogenic input of metals/metalloids to Lake Dojran sediments [23-24], calculated as:

$\mathrm{EF}=(\mathrm{M} / \mathrm{Al})_{\text {sample }} /(\mathrm{M} / \mathrm{Al})_{\text {crust }}$

where $\mathrm{M}_{\text {sample }}$ and $\mathrm{M}_{\text {crust }}$ are the levels of the investigated metals/metalloids ( $\mathrm{Au}, \mathrm{As}, \mathrm{Co}, \mathrm{Cr}, \mathrm{Cu}, \mathrm{Ni}$, $\mathrm{Pb}, \mathrm{Sb}$ and $\mathrm{Zn}$ ) in the sediment samples and uncontaminated crust material, respectively; and $\mathrm{Al}_{\text {sample }}$ and $\mathrm{Al}_{\text {crust }}$ are the levels of $\mathrm{Al}$ in sediment samples and uncontaminated crust material, respectively. Metal to aluminium ratios such as these are widely adopted, presumably because the concentrations of weathering products and their parent materials are generally comparable. Aluminium is also the normalizing element, levels of which are assumed not to be enriched owing to local contamination [25]. In this study, baseline values for $\mathrm{M}_{\text {crust }}$ and $\mathrm{Al}_{\text {crust }}$ were adopted from literature [26].

\section{Results and discussion}

\subsection{Physico-chemical characteristics of lake sediments}

The sampled lake sediments were characterized by an LOI content of less than $33 \%$; the highest value was detected at location D4, while slight variability was observed between the northern and southern parts of the lake. A strong and statistically significant correlation was found between LOI and total $\mathrm{C}$. Sediment $\mathrm{pH}$ values ranged between 5.8 and 7 . The measured $\mathrm{pH}$ of surficial sediments from Lake Kalimanci ranges between 5.5 and 7.5, and redox potential ranges between $-325 \mathrm{mV}$ and $+180 \mathrm{mV}$. The organic matter content lays in the following ranges in Lake Kalimanci surficial sediments [\%]: $\mathrm{C}_{\text {org }} 0.05-2.70, \mathrm{~N}_{\text {org }} 0.00-0.34, \mathrm{H}_{\text {org }} 0.29-5.97$ and $\mathrm{S}_{\text {org }} 0.00$ -2.13 , and has almost homogeneous concentrations of compounds through the lake.

\subsection{Mineralogy of lake sediments}

The exposed and underlying lithologies of the Dojran graben region are predominantly composed of gneisses, shales, amphibolites, marbles, granite porphyries, metarhyolites, metamorphic pyroclastites and Bjelasica granites, as well as the other metamorphic, sedimentary and volcanic rocks [18]. Surficial sediment samples mineralogy of the lake is thus closely related to these prevailing rocks. The mineralogical assemblage of the lake sediments is mostly comprised of quartz, feldspars (orthoclase, microcline and albite), clay minerals (kaolinite and montmorillonite/illite), calcite and micas (biotite, muscovite and lepidolite), along with minor augite and hornblende. Traces of zircon, epidote, glaucophane and goethite were found only sporadically. No significant changes in the predominant pattern of sediment mineral composition were observed throughout the investigated area.

The Lake Kalimanci surface sediment samples represent fine-grained, predominantly clay and silt sized lake sediment $(>0.0063 \mathrm{~mm})$ deposited after the construction of the artificial dam. Lake sediments generally reflect the mineralogical composition and the presence of ore in the surrounding area and bedrocks. According to XRD analysis, the lake sediments' main mineral phases are quartz, plagioclases (albite, anorthite), phengite, clinoclore, $\mathrm{K}$ feldspars, illite, and muscovite. Lake Kalimanci occasionally also contains calcite, sphalerite, epidote, gypsum, clinopyroxenes, olivine and pyrite, which in some cases contains As.

\subsection{Major elements in surficial lake sediments} Table 1.

Major element concentrations in Lake Dojran and Lake Kalimanci sediments are gathered in 
Table 1: Major element concentrations of Lake Dojran and Kalimanci surficial sediments.

\begin{tabular}{|c|ccccc|}
\hline Element & & Mean & Minimum & Maximum & $\begin{array}{c}\text { Std. } \\
\text { Dev. }\end{array}$ \\
\hline $\mathbf{S i}$ & & 219 & 70.7 & 270 & 75.0 \\
$\mathbf{A l}$ & & 68.5 & 30.0 & 88.0 & 21.0 \\
$\mathbf{F e}$ & & 40.3 & 16.9 & 60.6 & 15.2 \\
$\mathbf{M g}$ & & 9.92 & 4.00 & 21.4 & 6.39 \\
$\mathbf{C a}$ & Lake & 87.2 & 36.2 & 272 & 92.6 \\
$\mathbf{N a}$ & Dojran & 8.82 & 3.90 & 18.6 & 5.05 \\
$\mathbf{K}$ & & 17.9 & 9.00 & 22.4 & 5.23 \\
$\mathbf{T i}$ & & 4.00 & 1.60 & 6.20 & 1.51 \\
$\mathbf{P}$ & & 0.68 & 0.10 & 1.20 & 0.37 \\
$\mathbf{M n}$ & & 0.95 & 0.50 & 1.60 & 0.38 \\
\hline \hline $\mathbf{S i}$ & & 23.5 & 18.9 & 30.3 & 2.9 \\
$\mathbf{A l}$ & & 7.95 & 5.72 & 10.1 & 0.93 \\
$\mathbf{F e}$ & & 6.61 & 4.19 & 11.3 & 1.54 \\
$\mathbf{M g}$ & & 1.35 & 0.74 & 2.21 & 0.34 \\
$\mathbf{C a}$ & Lake & 3.82 & 1.19 & 7.5 & 1.6 \\
$\mathbf{N a}$ & Kalimanci & 1.14 & 0.29 & 2.06 & 0.43 \\
$\mathbf{K}$ & & 2.28 & 1.37 & 2.83 & 0.35 \\
$\mathbf{T i}$ & & 0.37 & 0.32 & 0.46 & 0.03 \\
$\mathbf{P}$ & & 0.16 & 0.09 & 0.23 & 0.04 \\
$\mathbf{M n}$ & & 0.57 & 0.18 & 1.33 & 0.25 \\
\hline
\end{tabular}

More than $65 \%$ of major elements in almost all surficial sediment samples (D1, D2, D3, D5 and D6) were accounted for Si-Al-Fe components, likely reflecting a relatively high proportion of quartz, feldspars, clay minerals and micas present in these sediments. The measured $\mathrm{Ca}$ and $\mathrm{Mg}$ concentrations (ranging approximately from 36.2 to $271.6 \mathrm{~g} \mathrm{~kg}^{-1} \mathrm{Ca}$ and 0.4 to $2.14 \mathrm{~g} \mathrm{~kg}^{-1} \mathrm{Mg}$ in samples D1, D2, D3, D5 and D6) could reflect the presence of feldspars, montmorillonite, micas, augite and/or hornblende, as well as low amounts of calcite. In contrast, $\mathrm{Ca}$ is the main component (271.6 $\mathrm{g} \mathrm{kg}^{-1}$ ) of sample D4, indicating increased levels of calcite and/or aragonite mollusc shells defining an authigenic source of $\mathrm{Ca}^{2+}$. Alkalis ( $\mathrm{K}$ and $\mathrm{Na}$, respectively) were found in all samples, probably bonded to feldspars, montmorillonite/illite, micas and/or augite. Mn concentrations ranged from 0.5 to $1.6 \mathrm{~g} \mathrm{~kg}^{-1}$, while phosphorous (P) content varied between 0.1 and $1.2 \mathrm{~g} \mathrm{~kg}^{-1}$, with no significant variation observed amongst the analyzed samples. Titanium (Ti) levels (1.6 to $6.2 \mathrm{~g} \mathrm{~kg}^{-}$ ${ }^{1}$ ) are likely connected with the presence of minerals such as micas, augite and/or hornblende.

Analysis of the spatial distribution of elements (Fig. 4) revealed the following patterns: Al and $\mathrm{Fe}$ abundances were highest on the NW side of the lake; the highest $\mathrm{Si}$ and $\mathrm{K}$ values were at the $\mathrm{N}$ and $\mathrm{S}$ ends of the lake; $\mathrm{Ca}$ distribution showed the opposite pattern to $\mathrm{Si}$; $\mathrm{Mg}, \mathrm{Na}, \mathrm{Mn}$ and $\mathrm{Ti}$ content decreased from $\mathrm{N}$ to $\mathrm{S}$; the highest $\mathrm{P}$ concentrations were dominated in the $\mathrm{W}$ and $\mathrm{SW}$ parts of Lake Dojran. These spatial distribution patterns are closely associated with the surrounding and underlying lithologies of the wider Dojran region.

Nearly $80 \%$ of the macro-chemical components account for Si-Al-Fe assemblages in terms of the major elements presents in the surficial Lake Kalimanci sediments. This compositional relationship reflects a relatively high proportion of quartz, feldspars and chlorite in surficial lake sediments, as was also indicated by X-ray Diffraction (XRD) analysis. The aforementioned minerals are mostly associated with the acidic to intermediate igneous rocks of the Osogovo Mountains. The absence of carbonate minerals nearby is reflected in the low $\mathrm{Ca}$ and $\mathrm{Mg}$ contents (approximately $10 \%$ of all components), which could be related to the presence of feldspars, 
chlorite and pyroxenes. The $\mathrm{Na}$ and $\mathrm{K}$ concentrations ( $\sim 7 \%$ of all components) are most probably related to the feldspar illite-muscovite content and the presence of amphiboles (hornblende). Relatively high concentration values of $\mathrm{Mn}\left(1,780-13,300 \mathrm{mg} \mathrm{kg}^{-1}\right.$ range) are possibly a result of oxic conditions during sampling, or of the low surface area of bottom sediments at some sampling points.

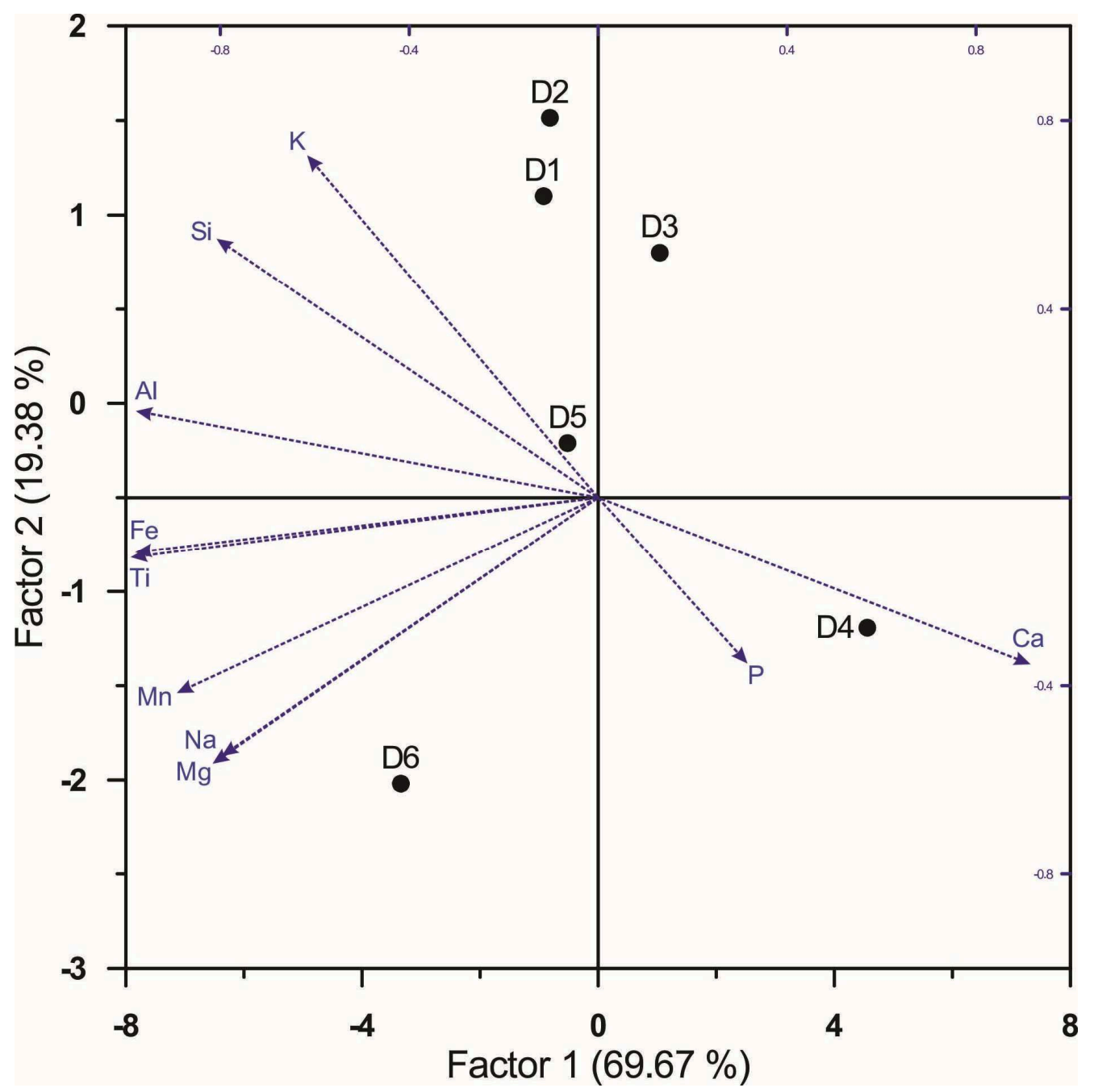

Fig. 4: Principal component analysis for major elements (Lake Dojran).

\subsection{Trace element concentrations of surficial lake sediments}

Trace element concentrations ( $\mathrm{Au}, \mathrm{As}, \mathrm{Co}, \mathrm{Cr}, \mathrm{Cu}, \mathrm{Ni}, \mathrm{Pb}, \mathrm{Sb}$ and $\mathrm{Zn}$ ) and their mean, minimum, maximum and standard deviation values in Lake Dojran and Lake Kalimanci sediments are summarized in Table 2.

Table 2: Mean, minimum, maximum and standard deviation values of the trace elements in the Lake Dojran and Lake Kalimanci surficial sediments.

\begin{tabular}{|c|c|c|c|c|c|c|c|c|c|c|c|}
\hline $\begin{array}{l}\text { t.e. } \\
\left(\mathrm{mg} \mathrm{kg}^{-1}\right)\end{array}$ & & $\mathrm{Au}$ & As & Co & $\mathrm{Cd}$ & $\mathrm{Cr}$ & $\mathrm{Cu}$ & $\mathrm{Ni}$ & $\mathrm{Pb}$ & $\mathrm{Sb}$ & $\mathrm{Zn}$ \\
\hline Mean & & 0.01 & 41.70 & 18.70 & b.d. & 6.10 & 34.80 & 53.80 & 26.30 & 1.90 & 88.30 \\
\hline Min & ake & 0.01 & 30 & 9 & b.d. & 3.40 & 18 & 27 & 16 & 1.20 & 46 \\
\hline Max & Dojran & 0.02 & 57 & 30 & b.d. & 8.10 & 54 & 75 & 46 & 2.70 & 109 \\
\hline Std.dev. & & 0.01 & 9.10 & 7 & b.d. & 1.70 & 13.70 & 18.70 & 10.60 & 0.60 & 24.20 \\
\hline
\end{tabular}




\begin{tabular}{|c|c|c|c|c|c|c|c|c|c|c|c|}
\hline Mean & & 0.03 & 67.69 & 19.89 & 56.58 & 59.37 & 415.12 & 45 & 6176.29 & 1.77 & 8371.94 \\
\hline Min & Lake & 0.01 & 27.90 & 11.70 & 16.50 & 27.37 & 144.40 & 21.70 & 1873.70 & 0.60 & 2944 \\
\hline Max & Kalimanci & 0.06 & 128.20 & 27.70 & 136 & 88.94 & 1161.90 & 79.30 & 16300 & 3.60 & 20900 \\
\hline Std.dev. & & 0.01 & 16.54 & 4.04 & 27.23 & 14.72 & 233.45 & 12.64 & 3491.02 & 0.71 & 4290.95 \\
\hline
\end{tabular}

Analysis showed that mean sediment trace element concentrations increase in the following order: $\mathrm{Au}<\mathrm{Sb}<\mathrm{Cr}<\mathrm{Co}<\mathrm{Pb}<\mathrm{Cu}<\mathrm{As}<\mathrm{Ni}<\mathrm{Zn}$. The distribution of these trace elements was not uniform over the whole lake area, with concentrations higher in the $\mathrm{W}$ ( $\mathrm{As}, \mathrm{Cr}, \mathrm{Cu}, \mathrm{Ni}, \mathrm{Pb}, \mathrm{Sb}$ and $\mathrm{Zn}), \mathrm{N}(\mathrm{Co})$ and $\mathrm{SW}(\mathrm{Au})$. This pattern reflects high values connected with the sampling points D5 and D6, which are located closest to the city of Novi Dojran (Fig. 5).
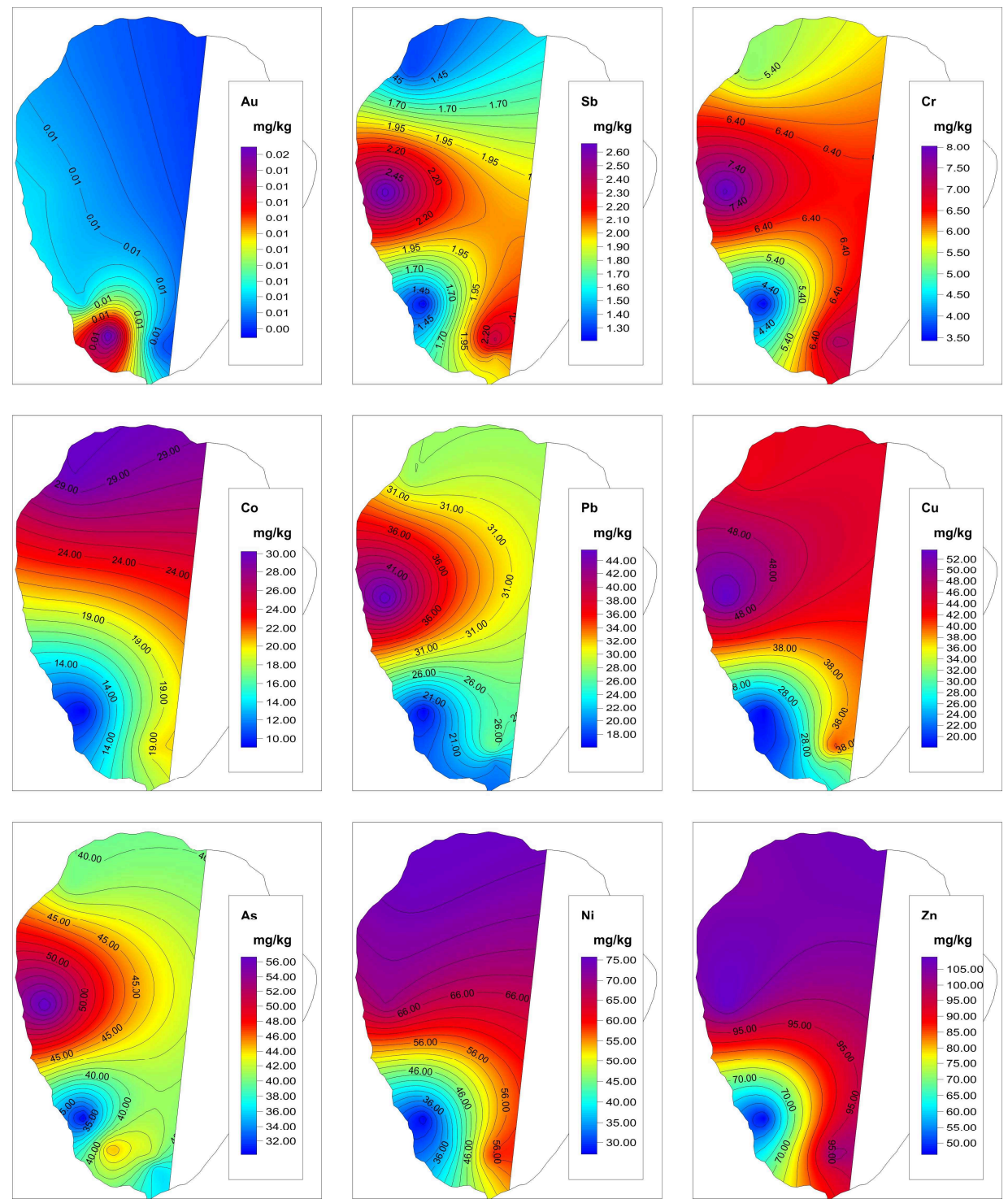

Fig. 5: Spatial distribution of trace elements (Lake Dojran).

The decreasing order of mean concentrations of the trace elements in Lake Kalimanci surficial sediments is $\mathrm{Zn}>\mathrm{Pb}>\mathrm{Cu}>\mathrm{As}>\mathrm{Cr}>\mathrm{Cd}>\mathrm{Ni}>\mathrm{Co}>\mathrm{Sb}>\mathrm{Au}$. Spatial distribution diagrams pointed out that trace elements like $\mathrm{Cu}, \mathrm{Pb}, \mathrm{Zn}, \mathrm{Ni}, \mathrm{Cd}$ and $\mathrm{Sb}$ were mostly increased between profiles two and three, which extend over the northern part of the lake. Cr, Co and As were observed to be heavily increased at the southern part of the lake. 
Sediment EF values around or lower than 1.0 indicate that the element in question originates predominantly from crustal material and/or weathering processes [27], whereas EF values much greater than 1.0 display the anthropogenic origin [28]. More recently, six contamination categories have been developed on the basis of enrichment factor values [25]:

\begin{tabular}{|l|l|}
\hline $\mathrm{EF}<3$ & minor enrichment (anthropogenic impact) \\
\hline $\mathrm{EF}=3-5$ & moderate enrichment \\
\hline $\mathrm{EF}=5-10$ & moderately severe enrichment \\
\hline $\mathrm{EF}=10-25$ & severe enrichment \\
\hline $\mathrm{EF}=25-50$ & very severe enrichment \\
\hline $\mathrm{EF}>50$ & extremely severe enrichment \\
\hline
\end{tabular}

Enrichment factor calculations revealed $\mathrm{Cr}, \mathrm{Zn}, \mathrm{Pb}, \mathrm{Cu}$ and $\mathrm{Co}$ to exhibit the lowest $\mathrm{EF}$ values among the trace elements (mean values $0.2,1.33,1.53$ and 1.63 , respectively); these five elements are thus only slightly enriched in surficial sediments of Lake Dojran. Calculated EF values for $\mathrm{Ni}, \mathrm{Au}$ and $\mathrm{Sb}$ signified moderate enrichment (mean value 3.13) with $\mathrm{Ni}$, moderately severe enrichment (mean value 5.5) with $\mathrm{Au}$ and severe enrichment (mean value 11.2) with $\mathrm{Sb}$. As had the highest average EF value (32.5) among the trace elements representing very severe enrichment in surficial sediments. The greatest overall EF values were determined in samples from locations D3 $(\mathrm{Au}), \mathrm{D} 5(\mathrm{As}, \mathrm{Cr}, \mathrm{Cu}, \mathrm{Ni}, \mathrm{Pb}, \mathrm{Sb}$ and $\mathrm{Zn})$ and $\mathrm{D} 6(\mathrm{Co}, \mathrm{Cu})$. Calculated EF revealed that surficial sediments from Lake Kalimanci are extremely severely enriched with $\mathrm{Pb}, \mathrm{Zn}$, and $\mathrm{Cd}$, meanwhile As and $\mathrm{Cu}$ shows very severe enrichment. Comparing to Lake Dojran, calculated EF is much higher in Lake Kalimanci than in Dojran.

Particle size and density play important roles in determining the chemistry and ecology of sediments. The clay/silt fraction $(<63 \mu \mathrm{m})$ has a high specific surface area per unit quantity of material and, due to surface coatings of $\mathrm{Fe}$ and $\mathrm{Mn}$ elements and natural organic material, is more likely to adsorb organic and trace elements contaminants [29-30]. Thus, most anthropogenic contaminants in lake Dojran are associated with the confirmed clay $(24.40 \%)$ and silt $(71.50 \%)$ fractions [18]. It can be concluded that the trace elements of Lake Dojran surficial sediments is derived from a number of different geogenic and anthropogenic sources. The geological background of the lake is generally dominated by metamorphic rocks [18] which are composed of minerals that can contain trace elements in their structure, as well as polymetallic mineralization in basic rocks [18] with arsenopyrite (FeAsS) and gold; these minerals all contribute to the enhanced levels of trace elements (especially As and $\mathrm{Au}$ ) found in lake sediments. Anthropogenic sources of trace elements include tourism activities taking place around the lake, resulting in increased traffic $(\mathrm{Pb})$ and coatings $(\mathrm{Sb})$, as well as urban inputs from the lake shore which discharge a large volume of wastewater, agrochemicals and landfill leachates from the nearest settlements. Solid and liquid wastes originating from urban areas are enriched with $\mathrm{Cu}, \mathrm{Pb}, \mathrm{Zn}$ and $\mathrm{Ni}$, while $\mathrm{Cu}, \mathrm{Pb}, \mathrm{Zn}, \mathrm{Cr}, \mathrm{Ni}$ and $\mathrm{Co}$ are also common constituents of many agrochemicals [31]. The spatial distribution of enrichment reflects the fact that sampling points D5 and D6 are located near the city of Novi Dojran and are in the vicinity of local hotel complexes.

Analysis via Pearson correlation matrix presented the following significantly positive correlations: As with $\mathrm{Pb}$; $\mathrm{Co}$ with $\mathrm{Zn}$ and $\mathrm{Ni}$; $\mathrm{Cr}$ with $\mathrm{Zn}$; $\mathrm{Cu}$ with $\mathrm{Pb}, \mathrm{Zn}$ and $\mathrm{Ni}$; $\mathrm{Ni}$ with $\mathrm{Zn}$; and finally $\mathrm{Sb}$ with $\mathrm{Cr}$ and Ni. PCA (Fig. 6) accounted for $85.88 \%$ of data variance in the first two ordination axes, revealing highly significant positive correlations between $\mathrm{As}, \mathrm{Cr}, \mathrm{Pb}$ and $\mathrm{Sb}$ and between $\mathrm{Co}, \mathrm{Cu}, \mathrm{Ni}$ and $\mathrm{Zn}$ at locations $\mathrm{D} 5$ and D6, and highly negative correlation was again confirmed between $\mathrm{Au}$ (location D3) and other trace elements. These relationships likely demonstrate possible co-contamination from the aforementioned geogenic and anthropogenic sources. Conversely, no correlations were noted between Au and any other element, suggesting that the nature of $\mathrm{Au}$ contamination might be from a different source (e.g. polymetallic mineralization) [32]. 


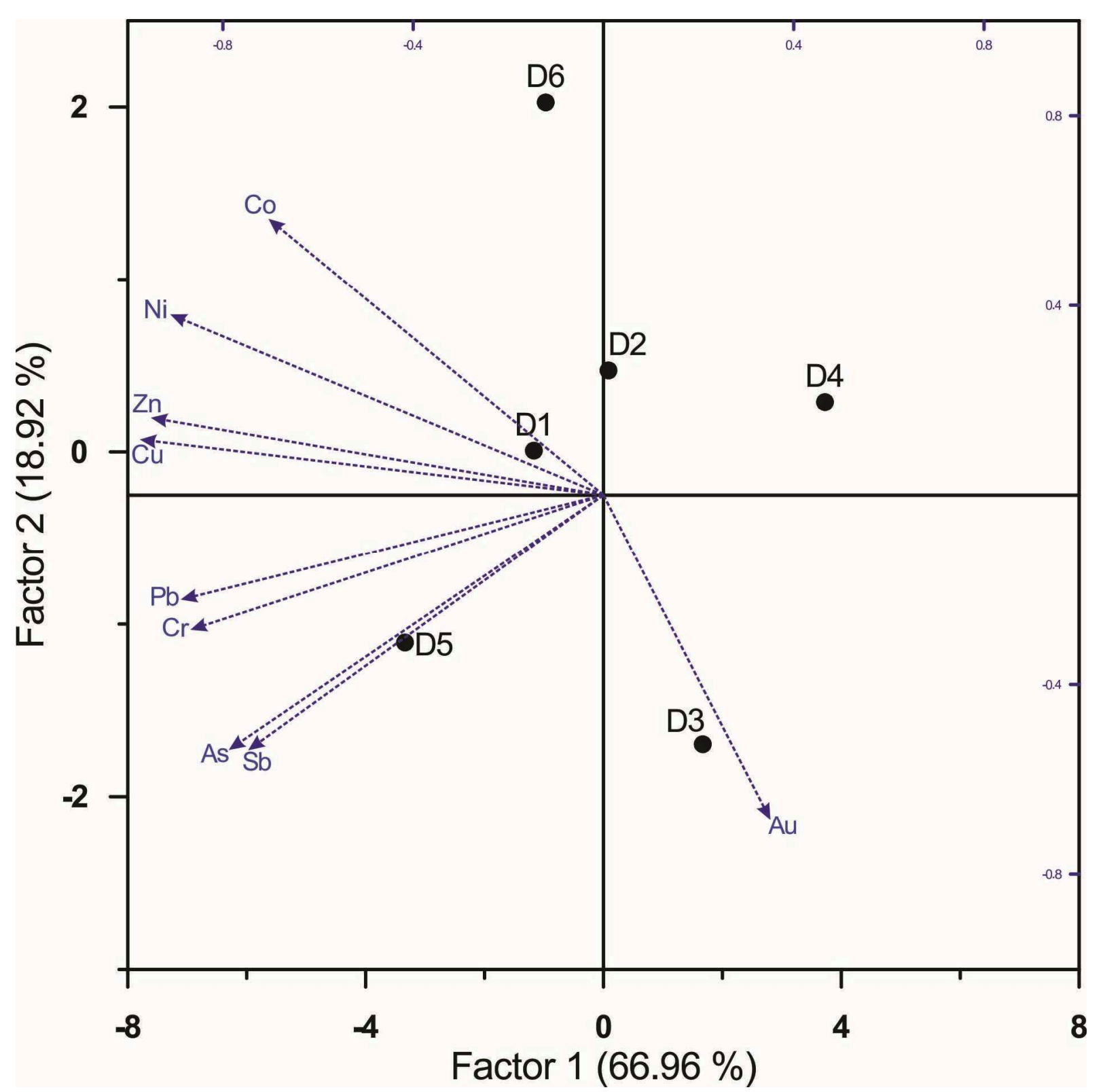

Fig. 6: Principal component analysis for trace elements (Lake Dojran).

\subsection{Mineralogy assemblage of the Anodonta cygnea and isotopic composition of inorganic C and $O$ in biogenic carbonate from Dojran lake}

Anodonta cygnea shells are composed of pure aragonite, together with a small amount of organic constituents (about 1\%). The XRD analyses were confirmed with SEM-EDS system analysis, as well.

Isotopic values results are represented in the Table 3 . An average value of $\delta^{13} \mathrm{C}_{\mathrm{VPDB}}$ is -2.17 $\%$ and the values range from $-1.72 \%$ to $-2.48 \%$. Deviations in $\delta^{13} \mathrm{C}_{\mathrm{VPDB}}$ values in molluscs shells are $0.76 \%$. The values of $\delta^{13} \mathrm{C}_{\mathrm{VPDB}}$ decrease with depth. $\delta^{13} \mathrm{C}_{\mathrm{VPDB}}$ values are very negative, indicating shells enrichment with light $\mathrm{C}$ isotope. Furthermore, these negative values of $\delta^{13} \mathrm{C}_{\mathrm{VPDB}}$ show that $\mathrm{CO}_{2}$ arising from decomposition of organic matter and by enhanced temperatures affects the carbon isotopic composition. $\mathrm{CO}_{2}$ is enriched with light $\mathrm{C}$ isotope, which lowers the values of $\delta^{13} \mathrm{C}_{\text {VPDB }}[33]$. 
Table 3: Inorganic C and $\mathrm{O}$ isotopic composition in Anodonta cygnea shells (\%o).

\begin{tabular}{llll}
\hline Sample & $\boldsymbol{\delta}^{\mathbf{1 3}} \mathbf{C}_{\text {VPDB }}$ & $\boldsymbol{\delta}^{\mathbf{1 3}} \mathbf{O}_{\text {VPDB }}$ & $\boldsymbol{\delta}^{\mathbf{1 3}} \mathbf{O}_{\text {SMOW }}$ \\
\hline D1 & -2.38 & 1.00 & 31.40 \\
D2 & -2.15 & 0.98 & 31.38 \\
D3 & -2.09 & 0.90 & 31.30 \\
D4 & -2.38 & 1.34 & 31.75 \\
D5 & -1.72 & 1.94 & 32.37 \\
D6 & -2.04 & 1.80 & 32.22 \\
\hline
\end{tabular}

An average value of $\delta^{18} \mathrm{O}_{\text {SMOW }}$ is $31.57 \%$ and $\delta^{18} \mathrm{O}_{\text {SMOW }}$ values vary between +30.81 and $+31.57 \%$. Deviations in $\delta^{18} \mathrm{O}_{\mathrm{SMOW}}$ values are estimated with $1.56 \%$. The values of $\delta^{18} \mathrm{O}_{\text {VPDB }}$ decrease with depth, also. $\delta^{18} \mathrm{O}$ signature in shells might be explained by precipitation of the carbonate from isotopically heavier oxygen lake water. The unusually heavy skeletal oxygen suggested calcification at elevated temperature and evaporation [33]. Evaporation influences the concentrations of dissolved compounds in water and the evaporation of light $\mathrm{H}_{2} \mathrm{O}$. This leads to water enrichment with heavy oxygen and consequently defines the isotopic composition of molluscs shells.

\subsection{Isotopic composition of inorganic $C$ and $O$ in surficial sediments from Dojran lake}

From Table 4, it is evident that $\delta^{13} \mathrm{C}_{\mathrm{VPDB}}$ are slightly negative indicating raised presence of light $\mathrm{C}$ isotope. The $\delta^{13} \mathrm{C}_{\mathrm{VPDB}}$ composition ranges from -6.45 to $-1.65 \%$ with an average value of $4.31 \%$. The values of $\delta^{13} \mathrm{C}_{\mathrm{VPDB}}$ increase with depth, where the presence of heavy $\mathrm{C}$ isotope prevails. This enrichment originates from methane production in sediment, which is depleted in heavy $\mathrm{C}$ isotope [34].

Table 4: Inorganic C and O isotopic composition in Lake Dojran sediments (\%o).

\begin{tabular}{llll}
\hline Sample & $\boldsymbol{\delta}^{\mathbf{1 3}} \mathbf{C}_{\mathbf{V P D B}}$ & $\boldsymbol{\delta}^{\mathbf{1 3}} \mathbf{O}_{\mathbf{V P D B}}$ & $\boldsymbol{\delta}^{\mathbf{1 3}} \mathbf{O}_{\text {SMOW }}$ \\
\hline D1 & -4.98 & -4.79 & 25.43 \\
D2 & -5.06 & -5.84 & 24.35 \\
D3 & -4.50 & -1.79 & 28.53 \\
D4 & -2.02 & 1.49 & 31.90 \\
D5 & -1.65 & 1.02 & 31.42 \\
D6 & -6.45 & -5.60 & 24.60 \\
\hline
\end{tabular}

$+31.90 \%$. An average value $\delta^{13} \mathrm{O}_{\text {SMOW }}$ is $+27.99 \%$. $\delta^{13} \mathrm{O}_{\text {VPDB }}$ results increase with depth. Lake Dojran sediments are strongly affected by evaporation effect, revealing that the values of $\delta^{13} \mathrm{O}_{\text {SMOW }}$ are much closer to $\delta^{13} \mathrm{O}_{\text {SMOW }}$ values of marine sediment than $\delta^{13} \mathrm{O}_{\text {SMOW }}$ values of freshwater sediment. $\delta^{13} \mathrm{O}_{\mathrm{SMOW}}$ results for marine sediments range from +26 to $+32 \%$ (after [35]).

\subsection{Trace element composition of fish and frog species selected from Lake Kalimanci and fish species from Lake Dojran}

Analyses identified particularly high levels for $\mathrm{Cr}, \mathrm{Hg}, \mathrm{Ni}$ and $\mathrm{Pb}$ in fishes (Vimba melanops) and frog (Rana temporaria) samples from Lake Kalimanci with mean values $\left[\mathrm{\mu gkg}^{-1}\right]$ : $1090-6.5,339-117,567-5100$ and $1127-435$, respectively. Meanwhile, the contents of $\mathrm{Cr}, \mathrm{Hg}$, $\mathrm{Ni}$ and $\mathrm{Pb}$ in fishes samples (Rutilus rutilus dojranensis from Lake Dojran are a bit lower $\left[\mathrm{\mu gkg}^{-1}\right]$ : 2320, 1690, 700 and 50. Complete results are presented in Table 5. 
Table 5: Mean trace element contents in freshwater fishes and frog samples (Lake Dojran and Lake Kalimanci).

\begin{tabular}{|c|c|c|c|c|c|c|c|c|c|c|c|c|c|c|}
\hline Sample & & & Cd & Co & $\mathbf{C u}$ & $\mathrm{Cr}$ & $\mathbf{H g}$ & Mo & $\mathbf{N i}$ & $\mathbf{P b}$ & $\mathbf{S b}$ & Se & $\mathbf{Z n}$ & As \\
\hline Detection Limit & & Unit & 0.1 & 0.5 & 20 & 10 & 5 & 1 & 0.1 & 10 & 0.2 & 0.2 & 0.2 & 5 \\
\hline \multirow[t]{2}{*}{$\begin{array}{l}\text { Vimba } \\
\text { melanops }\end{array}$} & & $\underset{\mathbf{k g}^{-1}}{\mu \mathrm{g}}$ & 7 & 30.9 & 1653 & 1090 & 338.7 & 58.3 & 567 & 1127 & 3.1 & 1433 & 46500 & 295 \\
\hline & $\begin{array}{c}\text { Lake } \\
\text { Kalimanci }\end{array}$ & & & & & & & & & & & & & \\
\hline $\begin{array}{l}\text { Rana } \\
\text { temporaria }\end{array}$ & & $\underset{\mathbf{k g}^{-1}}{\mu \mathrm{g}}$ & 29.9 & 112 & 1520 & 6.51 & 117 & 268 & 5100 & 435 & 8.5 & 650 & 80300 & 183 \\
\hline $\begin{array}{l}\text { Rutilus rutilus } \\
\text { dojranensis }\end{array}$ & $\begin{array}{c}\text { Lake } \\
\text { Dojran }\end{array}$ & $\underset{\mathbf{k g}^{-1}}{\mu \mathrm{g}}$ & 27.3 & 33.9 & 1820 & 2320 & 1690 & 63 & 7000 & 50 & 5.9 & 13000 & 942000 & 738 \\
\hline
\end{tabular}

\section{Conclusion}

In the present study the mineralogical, geochemical and isotopic properties of of recent surficial sediments from the Lake Dojran and Lake Kalimanci (FYRM) and shells of Anodonta cygnea from Lake Dojran were examined in detail.

Mineralogical analysis revealed that the lake's surficial sediment mineralogy is closely related to the prevailing metamorphic, volcanic and igneous rocks of the Dojran region. The mineralogical assemblage of lake sediments is mostly composed of quartz, feldspars, clay minerals, calcite and micas, along with minor amounts of augite and hornblende.

More than $65 \%$ of major elements in almost all samples were accounted for Si-Al-Fe components, reflecting abovementioned mineral association. Mean trace element concentrations in Lake Dojran sediments increase in the following order: $\mathrm{Au}<\mathrm{Sb}<\mathrm{Cr}<\mathrm{Co}<\mathrm{Pb}<\mathrm{Cu}<\mathrm{As}<\mathrm{Ni}<$ Zn. According to calculated EF values, surficial Lake Dojran sediments $(0-5 \mathrm{~cm})$ are little enriched with $\mathrm{Cr}, \mathrm{Zn}, \mathrm{Pb}, \mathrm{Cu}$ and $\mathrm{Co}$, moderately enriched with $\mathrm{Ni}, \mathrm{Au}$ and $\mathrm{Sb}$, moderately severely enriched with $\mathrm{Au}$, severely enriched with Sb and very severely enriched with As. The abovementioned enrichment originates from a number of different geogenic (geological background and polymetallic mineralization with arsenopyrite (FeAsS) and gold (Au)) and anthropogenic sources. The latter include various tourism activities which take place around the lake - and the associated increase in traffic $(\mathrm{Pb})$ and coatings $(\mathrm{Sb})$ - as well as urban inputs from the lake shore which discharge a considerable volume of wastewater, agrochemicals and landfill leachates.

The mineralogy of Anodonta cygnea shells is aragonitic. $\delta^{13} \mathrm{C}_{\mathrm{VPDB}}$ values in Anodonta cygnea shells are ranging from $-1.72 \%$ to $-2.48 \%$, showing shells enrichment with light $\mathrm{C}$ isotope. The values of $\delta^{13} \mathrm{C}_{\mathrm{VPDB}}$ decrease with depth indicating that $\mathrm{CO}_{2}$ arising from decomposition of organic matter and by enhanced temperatures, affects the carbon isotopic composition. $\delta^{18} \mathrm{O}_{\text {SMOW }}$ shell values vary between +30.81 and $+31.57 \%$. Stable isotope signatures showed that the biogenic carbonate fraction from the Lake Dojran was precipitated in water where the isotopic ratios were controlled by the precipitation evaporation balance.

The $\delta^{13} C_{V P D B}$ signature in Lake Dojran sediments range from -6.45 to $-1.65 \%$ and $\delta^{13} C_{V P D B}$ values are increasing with depth. Thus, heavy $\mathrm{C}$ isotope dominates in depth. This enrichment originates from methane production in sediment, which is decreased with heavy $\mathrm{C}$ isotope. Measured $\delta^{13} \mathrm{O}_{\text {SMOw }}$ sediment values vary from $24.34 \%$ to $31.90 \%$. Lake Dojran sediments are strongly affected by evaporation effect, defining $\delta^{13} \mathrm{O}_{\text {SMOW }}$ values in sediments closer to marine sediments. 
When both lakes are compared, it can be concluded, that Lake Kalimanci is much more polluted with potentialy toxic elements, such as metals and metalloids, than Lake Dojran. Major cause for such heavy pollution in lake environment is related to nearby active mining. The Sasa mine, where $\mathrm{Pb}$ and $\mathrm{Zn}$ concentrates are produced, has major influence on entire lake ecosystem. Furthermore, after Sasa tailings dam failure in year 2003, all elements are heavily increased. For this reason also fish samples from Lake Kamenica contain higher contents of toxic elements than those from Lake Dojran. At the end, our intention was to compare shells from both lakes, but regarding to such heavy pollution in Lake Kalimanci, no shells could be found.

\section{Acknowledgements}

This study was financially supported by the ARRS Programme group P1-0195 (Geochemical and structural processes) and COST Action TD0903 project: Understanding and manipulating enzymatic and proteomic processes in biomineralization.

\section{REFERENCES}

[1] A. O. Oyewale, I. Musa, Pollution assessment of the lower basin of Lakes Kainji/Jebba, Nigeria: heavy metal status of the waters, sediments and fishes, Environ. Geochem. Health 28 (2006) 273281.

[2] M. H. Bibi, F. Ahmed, H. Ishiga, Assessment of metal concentrations in lake sediments of southwest Japan based on sediment quality guidelines, Environ. Geol. 52 (2007) 625-639.

[3] S. Kumar Das, J. Routh, A.N. Roychoudhury, J. Val Klump, Major and trace element geochemistry in Zeekoevlei, South Africa: A lacustrine record of present and past processes, Appl. Geochem. 23 (2008) 625-639.

[4] E. Maltby, Soil and wetland functions, in: Gerakis P. A. (Ed.), Conservation and Management of Greek Wetlands. (1992) The IUCN Wetlands Programme, pp. 9-60.

[5] K.P. Singh, D. Mohan, V.K. Singh, A. Malik, Studies on distribution and fractionation of heavy metals Gomti river sediments - a tributary of the Ganges, J. Hydrol. 312 (2005) 14-27.

[6] H. Ghrefat, N. Yusuf, Assessing Mn, Fe, Cu, Zn, and Cd pollution in bottom sediments of Wadi Al-Arab Dam, Jordan, Chemosphere 65 (2006) 2114-2121.

[7] A. Kabata-Pendias, H. Pendias, Trace Elements in Soils and Plants. 3rd ed. CRC Press, Boca Raton, FL (2001).

[8] A. Khaled, A. El Nemr, A. El Sikaily, An assessment of heavy-metal contamination in surface sediments of the Suez Gulf using geoaccumulation indexes and statistical analysis, Chem. Ecol. 22(3) (2006) 239-252.

[9] A. Demirak, F. Yilmaz, Levent, A. Tuna, N. Ozdemir, Heavy metals in water, sediment and tissues of Leuiscus cephalus from a stream in southwestern Turkey, Chemosphere 63 (2006) 14511458.

[10] V.U. Devi, Bioaccumulation and metabolic effects of cadmium on marine fouling dressinid bivalve, Mytilopsis sallei (Recluz), Arch. Environ. Contam. Toxicol. 31 (1996) 47-53.

[11] G. Moura, L. Vilarinho, A.C. Santos, J. Machado, Organic compounds in the extrapallial fluid and haemolymph of Anodonta Cygnea (L.) with emphasis on the seasonal biomineralization process, Comp. Biochem. Physiol. Part B. 125 (2000) 293-306. 
[12] S. Gintenreiter, J. Ortel, H. Nopp, Effects of different dietary levels of cadmium, lead, copper and zinc on the vitality of the forest pest insect Lymantria dispar L. (Lymantriidae, Lepid), Arch. Environ. Cont. Toxicol. 25 (1993) 62-66.

[13] J.G. Arnason, B.A. Fletcher, A 40+ year record of Cd, $\mathrm{Hg}, \mathrm{Pb}$ and $\mathrm{U}$ deposition in sediments of Patroon Reservoir, Albany County, NY, USA, Environ. Pollut. 123 (2003) 383-391.

[14] K. Aysegül, N. Balkis, M. Erkan, H. Balkais, A. Aksu, M.S. Ersan, Total metal levels in crayfishes Astacus leptodactylus (Escholtz, 1823), and surface sediments in Lake Terkos, Turkey, Environ. Monitor. Assess. 169 (2010) 358-395.

[15] C.X. Fan, Y.X. Zhu, Z.J. Ji, L. Zhang, L.Y. Yang,. Characteristics of the pollution of heavy metals the sediments of Yilihe River, Taihu Basin, J. Lake Sci. 14(3) (2002) 235-241.

[16] P. Gramatica, F. Battaini, E. Giani, E. Papa, R.J.A. Jones, D. Preatoni, R.M. Cenci, Analysis of mosses and soils for quantifying heavy metal concentrations in Sicily: A multivariate and spatial analytical approach, Environ. Sci. Pollut. Res. 1 (2006) 28-36

[17] W. Tylmann, K. Lysek, M. Kinder, J. Pempkowiak, Regional Pattern of Heavy Metal Content in Lake Sediments in Northern Poland, Water Air Soil Pollut. 216 (2011) 217-228.

[18] R. Stojanov, E. Micevski, Geologija na Dojransko Ezero I negovata okolina, Prilozi, 10(1-2) (1989) 35-37.

[19] R.Stojanov, J. Obradović, S. Djurić, Dojran Lake Dark Mud. Simposium - Annual Meeting (Dojran-Štip), Faculty of mining and geology, (1997) pp. 221-225.

[20] H. Ehrlich, Chitin and collagen as universal and alternative templates in biomineralization, Int. Geol. Rev. 52 (2010) 661-699.

[21] F. Jabeen, A.S. Chaudhry, Environmental impacts of anthropogenic activities on the mineral uptake in Oreochromis mossambicus from Indus River in Pakistan, Environ. Monit. Assess. 166 (2009) 641-651.

[22] U.S. EPA-Environmental Protection Agency. Guidelines for Ecological Risk Assessment, 188 pp (1998).

[23] A. L. W. Kemp, R. L. Thomas, C. I. Dell, J.M. Jaquet, Cultural impact on the geochemistry of sediments in Lake Erie, Can. J. Fish. Aquat. Sci. 33 (1976) 440-85.

[24] P.C. Van Metre, E. Callender, Water quality trends in white rock creek basin from 1912-1994 identified using sediment cores from white rock lake reservoir, Dallas, Texas, J. Paleolimnol. 17 (1997) 239-249.

[25] C.H. Chen, C.M. Kao, C.F. Chen, C. D. Dong, Distribution and accumulation of heavy metals the sediments of Kaohsiung Harbor, Taiwan, Chemosphere 66(8) (2007) 1431-1440.

[26] S.R. Taylor, S. M. McLennan, The geochemical evaluation of the continental crust, Rev. Geophys. 33 (1995) 241-265.

[27] J. Zhang, C.L. Liu, Riverine composition and estuarine geochemistry of particulate metals in China - weathering features, anthropogenic impact and chemical fluxes, Est. Coast. Shelf Sci. 54 (2002) 1051-1070. 
[28] P. Szefer, G.P. Glasby, K. Szefer, J. Pempkowiak, R. Kaliszan, Heavy-metal pollution in superficial sediments from the southern Baltic Sea of Poland, J. Environ. Sci. Health 31A (1996), 2723-2754.

[29] B.T. Hart, Uptake of trace metals by sediments and suspended particulates: A review, Hydrobiologia 91 (1982) 299-313.

[30] W. Maher, G.E. Batkey, I. Lawrence, Assessing the health of sediment ecosystems: Use of chemical measurements, Freshw. Biol. 41 (1999) 361-372.

[31] U. Förstner, G. T. W. Wittmann, Metal Pollution in the Aquatic Environment. Springer, Berlin, Heidelberg, New York (1981).

[32] S. Olivares-Rieumont, D. Rosa, L. Lima, D.W. Graham, K.D. Alessandro, J. Borroto, F. Martínez, J. Sánchez, Assessment of heavy metal levels in Almendares River sediments-Havana City, Cuba, Water Resour. 39 (2005) 3945-3953.

[33] J. Hoefs, Stable Isotope Geochemistry. Berlin, Springer Verlag, (1997) 240 pp.

[34] N. Ogrinc, S. Lojen, J. Faganeli, The sources of dissolved inorganic carbon in pore waters of lacustrine sediment, Water Air Soil Pollut. 99 (1997) 333-341.

[35] Wedepohl. Handbook of geochemistry. Berlin, Springer, Verlag (1978) pp. 1-5. 